\title{
TRPC1/TRPC3 channels mediate lysophosphatidylcholine- induced apoptosis in cultured human coronary artery smooth muscles cells
}

\author{
Yuan Wang ${ }^{1,2}$, Yan Wang ${ }^{1}$ and Gui-Rong Li ${ }^{1,2}$ \\ ${ }^{1}$ Xiamen Cardiovascular Hospital, Medical School of Xiamen University, Xiamen, Fujian, China \\ 2 Department of Medicine, Li Ka Shing Faculty of Medicine, University of Hong Kong, Pokfulam, Hong Kong, China \\ Correspondence to: Yan Wang, email:wy@medmail.com.cn \\ Gui-Rong Li, email: grli8@outlook.com \\ Keywords: Iysophosphatidylcholine; cell viability; apoptosis; transient receptor potential channels; Pathology Section \\ Received: March 01,2016 Accepted: July 09, $2016 \quad$ Published: July 26, 2016
}

\section{ABSTRACT}

The earlier study showed that lysophosphatidylcholine (IysoPC) induced apoptosis in human coronary artery smooth muscle cells (SMCs); however, the related molecular mechanisms are not fully understood. The present study investigated how IysoPC induces apoptosis in cultured human coronary artery SMCs using cell viability assay, flow cytometry, confocal microscopy, and molecular biological approaches. We found that IysoPC reduced cell viability in human coronary artery SMCs by eliciting a remarkable $\mathrm{Ca}^{2+}$ influx. The effect was antagonized by $\mathrm{La}^{3+}$, SKF-96365, or Pyr3 as well as by silencing TRPC1 or TRPC3. Co-immunoprecipitation revealed that TRPC1 and TRPC 3 had protein-protein interaction. Silencing TRPC1 or TRPC 3 countered the lysoPC-induced increase of $\mathrm{Ca}^{2+}$ influx and apoptosis, and the pro-apoptotic proteins Bax and cleaved caspase- 3 and decrease of the anti-apoptotic protein $\mathrm{Bcl}-2$ and the survival kinase pAkt. These results demonstrate the novel information that TRPC1/ TRPC 3 channels mediate lysoPC-induced $\mathrm{Ca}^{2+}$ influx and apoptosis via activating the pro-apoptotic proteins Bax and cleaved caspase-3 and inhibiting the anti-apoptotic protein Bcl-2 and the survival kinase pAkt in human coronary artery SMCs, which implies that TRPC1/TRC3 channels may be the therapeutic target of lysoPC-induced disorders such as atherosclerosis.

\section{INTRODUCTION}

Oxidized low-density lipoprotein (ox-LDL) is a well-known culprit of atherogenesis, which causes a series of aberrant initial changes in vascular smooth muscle cells (SMCs) including lipid homeostasis and deposition, dysfunction of $\mathrm{Ca}^{2+}$ homeostasis, and apoptosis $[1,2]$. Lysophosphatidylcholine (lysoPC) is a major component of ox-LDL [3, 4], and induces apoptosis of vascular endothelial cells and SMCs [5-7]. However, the related molecular mechanisms are not fully understood.

$\mathrm{Ca}^{2+}$ is a well-known second messenger that regulates a wide range of cell functions including excitation-contraction coupling, excitation-secretion coupling, gene transcription, cell growth, differentiation, apoptosis, membrane fusion, and ion channel activation [8-11]. Previous studies reported that lysoPC induced an sustained increase in intracellular free $\mathrm{Ca}^{2+}\left(\mathrm{Ca}^{2+}\right)$ in human [12] and rabbit [13] coronary artery SMCs and in human umbilical vein endothelial cells [14] and in cultured human corporal SMCs [15]. The participation of transient receptor potential (TRP) channels was proposed in these reports. However, TRP channels contains 6 families (TRPC, TRPV, TRPM, TRPP, TRPML, and TRPA) with different isoforms in each subfamily [16]. It is unknown which TRP channels mediate the nonselective cation current and/or $\mathrm{Ca}^{2+}$ entry, and lysoPC-induced apoptosis. The present study was therefore designed to determine the potential molecular pathway that mediates the lysoPCinduced $\mathrm{Ca}^{2+}$ influx and/or apoptosis in human coronary artery SMCs. Our results revealed that TRPC1/TRPC3 channels were involved in mediating lysoPC-induced $\mathrm{Ca}^{2+}$ influx and apoptosis by increasing the pro-apoptosis kinases Bax and cleaved caspase- 3 and inhibiting the antiapoptosis kinase Bcl-2 and the surviving kinase p-Akt in human coronary artery SMCs. 


\section{RESULTS}

\section{Effect of lysoPC on cell viability}

The previous studies reported that lysoPC decreased cell viability in cultured rat aortic artery SMCs [17]. The effect of lysoPC on cell viability was confirmed with MTT assay in human coronary artery SMCs. Figure 1A illustrates that a $72 \mathrm{~h}$ incubation of lysoPC $(10-90 \mu \mathrm{mol} / \mathrm{L})$ induced a reduction of cell viability in a concentrationdependent manner, and significant decrease of viability was observed at concentrations greater than $30 \mu \mathrm{mol} / \mathrm{L}$ lysoPC. The time-dependent inhibition of cell viability was determined with 10, 30 and $60 \mu \mathrm{mol} / \mathrm{L}$ lysoPC (Figure 1B). Significant reduction of cell viability was observed with 30 and $60 \mu \mathrm{mol} / \mathrm{L}$ at $24-72 \mathrm{~h}$. LysoPC at $60 \mu \mathrm{mol} / \mathrm{L}$ demonstrated a remarkable inhibitory effect on cell viability,

\section{Apoptosis induced by lysoPC}

Whether the reduced cell viability is a result of inhibition of cell cycling progression was analyzed with flow cytometry. Figure $2 \mathrm{~A}$ shows the percent values of cells at different cycling progression phases. No significant change in cell cycling progression phases was observed in cells treated with 30 or $60 \mu \mathrm{mol} / \mathrm{L}$ lysoPC for $24 \mathrm{~h}$, suggesting that the decreased viability by lysoPC is not related to cell cycling arrest in human coronary artery SMCs.

To determine whether the reduced cell viability is related to apoptosis, flow cytometry analysis was further performed in human coronary artery SMCs treated with 30 or $60 \mu \mathrm{mol} / \mathrm{L}$ lysoPC (24 h) and stained with Annexin V-FITC, showing reduced viability and increased apoptosis (Figure 2B). Figure 2C shows the mean percent values of cell viability, early apoptosis, late apoptosis and death. The cell viability was reduced by 30 and 60 $\mu \mathrm{mol} / \mathrm{L}$ lysoPC $(n=3$ individual experiments, $P<0.05$ or $P<0.01 v s$. control) similar to MTT assay (Figure 1). The percent values of cell populations at early apoptosis and late apoptosis were increased from $1.8 \pm 0.5 \%$ and $5.9 \pm 0.8 \%$ of control to $4.8 \pm 0.8 \%$ and $10.0 \pm 1.8 \%$ by $30 \mu \mathrm{mol} / \mathrm{L}$ lysoPC $(n=3, P<0.05 v s$. vehicle control), to $12.21 .8 \%$ and $11.8 \pm 2.0 \%$ by $60 \mu \mathrm{mol} / \mathrm{L}$ lysoPC $(n=$ $3, P<0.01 v s$. vehicle control). The dead cells were not significantly increased.

LysoPC-induced apoptosis was confirmed by TUNEL assay in human coronary artery SMCs treated with 30 or $60 \mu \mathrm{mol} / \mathrm{L}$ lysoPC for $24 \mathrm{~h}$ (Figure 2D). The cells with TUNEL-positive nuclei (green) were significantly increased by 30 and $60 \mu \mathrm{mol} / \mathrm{L}$ lysoPC $(16.0 \pm 2.2 \%$ and $25.3 \pm 4.3 \%$ vs. $5.07 \pm 1.7 \%$ of vehicle control $(n=3, P<$ 0.01 ) (Figure 2E). In addition, caspase-3 activity was determined in cells treated with 30 or $60 \mu \mathrm{mol} / \mathrm{L}$ lysoPC for $24 \mathrm{~h}$. The ratio of caspase-3 activity was increased to $1.3 \pm 0.1$ and $1.9 \pm 0.1$ of vehicle control respectively by $30 \mu \mathrm{mol} / \mathrm{L}$ and $60 \mu \mathrm{mol} / \mathrm{L}$ lysoPC $(n=3, P<0.05$ or $P<$ 0.01 ) (Figure $2 \mathrm{~F}$ ). These results indicate that the reduced viability by lysoPC is related to induction of apoptosis in human coronary artery SMCs.

\section{Effect of lysoPC on $\mathrm{Ca}^{2+}{ }_{\mathrm{i}}$}

A previous study demonstrated that lysoPC induced a sustained $\mathrm{Ca}^{2+}$ increase in human coronary artery SMCs, and the potential mediation of TRP channels was proposed [12]; however, the involvement of specific TRP channels was not understood. To specify which TRP channels mediate the lysoPC-induced $\mathrm{Ca}^{2+}{ }_{i}$ increase and apoptosis, we determined the effect of lysoPC on cytosolic $\mathrm{Ca}^{2+}$ by a confocal laser scanning technique in human coronary artery SMCs with different pharmacological tools.

Application of $10 \mu \mathrm{mol} / \mathrm{L}$ lysoPC induced little change of $\mathrm{Ca}^{2+}$, level, while $30 \mu \mathrm{mol} / \mathrm{L}$ or $60 \mu \mathrm{mol} / \mathrm{L}$ lysoPC induced a significant sustained $\mathrm{Ca}^{2+}$ increase within $2 \mathrm{~min}$ in human coronary artery SMCs. Significant increase of relative $\mathrm{Ca}^{2+}$, level at end of experiments was observed with $30 \mu \mathrm{mol} / \mathrm{L}$ or $60 \mu \mathrm{mol} / \mathrm{L}$ (Figure $3 \mathrm{~A}, n$ $=26-28, P<0.01 v s .10 \mu \mathrm{mol} / \mathrm{L})$. In contrast, omitting bath $\mathrm{Ca}^{2+}\left(\mathrm{Ca}^{2+}\right.$-free plus $1 \mathrm{mmol} / \mathrm{L}$ EGTA $)$ abolished the sustained calcium increase induced by $30 \mu \mathrm{mol} / \mathrm{L}$ lysoPC (Figure 3C, $n=26-28, P<0.01$ vs. $1.8 \mathrm{mmol} / \mathrm{L} \mathrm{Ca}^{2+}$ ), indicating that increase of $\mathrm{Ca}^{2+}{ }_{i}$ by lysoPC is related to $\mathrm{Ca}^{2+}$ influx

To investigate the potential involvement of $\mathrm{Ca}^{2+}$ influx in lypoPC-induced apoptosis, the apoptosis was analyzed by flow cytometry in cells incubated in a culture medium with reducing $\mathrm{Ca}^{2+}$ from $1.8 \mathrm{mmol} / \mathrm{L}$ to $0.9 \mathrm{mmol} / \mathrm{L}$. Figure $3 \mathrm{C}$ shows the cell viability, early apoptosis, late apoptosis and death in cells treated with lysoPC $(60 \mu \mathrm{mol} / \mathrm{L})$ treatment for $24 \mathrm{~h}$. LysoPC-induced decrease of cell viability and increase of early and late apoptosis were reduced in culture medium containing $0.9 \mathrm{mmol} / \mathrm{L} \mathrm{Ca}^{2+}$ (Figure 3D, $n=3, P<0.05$ or $P<0.01$ vs. $1.8 \mathrm{mmol} / \mathrm{L} \mathrm{Ca}^{2+}$ ). This suggests that lysoPC-induced apoptosis is related to the increase of $\mathrm{Ca}^{2+}$ influx by lysoPC.

\section{Effect of TRP channel blockade on apoptosis induced by lysoPC}

Earlier reports demonstrated that $\mathrm{Ca}^{2+}$ flux was mainly mediated by voltage-gated $\mathrm{Ca}^{2+}$ channels (VGCC), $\mathrm{Na}^{+}-\mathrm{Ca}^{2+}$ exchanger (NCX), and/or TRP channels [18-21]. To obtain information on which pathway mediates the $\mathrm{Ca}^{2+}$ influx induced by lysoPC the L-type $\mathrm{Ca}^{2+}$ channel blocker nifedipine, the NCX inhibitor KB-R7943 [22], and nonselective TRP channel blocker $\mathrm{La}^{3+}$ were employed 

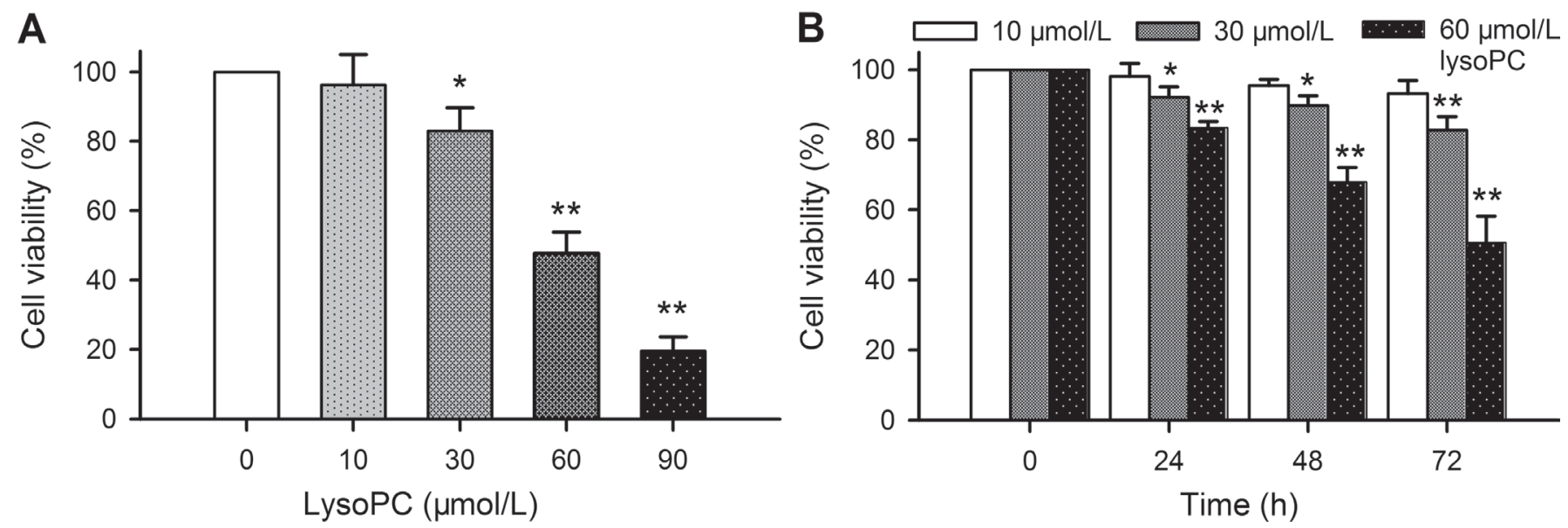

Figure 1: Effect of lysoPC on cell viability. A. Cell viability was determined with MTT assay in human coronary artery SMCs incubated with $10,30,60$, and $90 \mu \mathrm{mol} / \mathrm{L}$ lysoPC for $72 \mathrm{~h}$. Data are mean $\pm \mathrm{SEM}\left(* P<0.05,{ }^{*} P<0.01 v s\right.$. control, $0 \mu \mathrm{mol} / \mathrm{L}$ lysoPC). B. Cell viability was determined in human coronary artery SMCs incubated with 10, 30, and $60 \mu \mathrm{mol} / \mathrm{L}$ lysoPC for $24-72 \mathrm{~h}$. Data are mean $\pm \mathrm{SEM}(n=3$ individual experiments, ${ }^{*} P<0.05, * * P<0.01$ vs. 0 day).

A

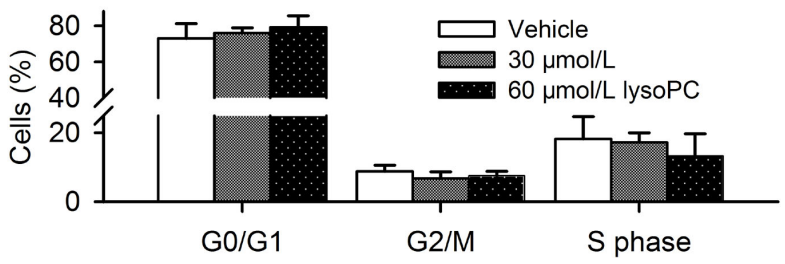

B

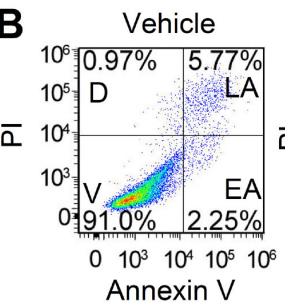

LysoPC $30 \mu \mathrm{mol} / \mathrm{L}$ \begin{tabular}{l|r}
$10^{6}$ & $1.50 \%$ \\
$10^{5}: \mathrm{D}$ & $10.8 \%$ \\
\hline
\end{tabular}

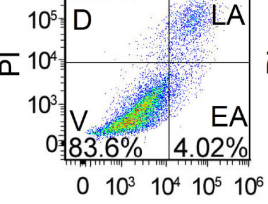
Annexin $\mathrm{V}$

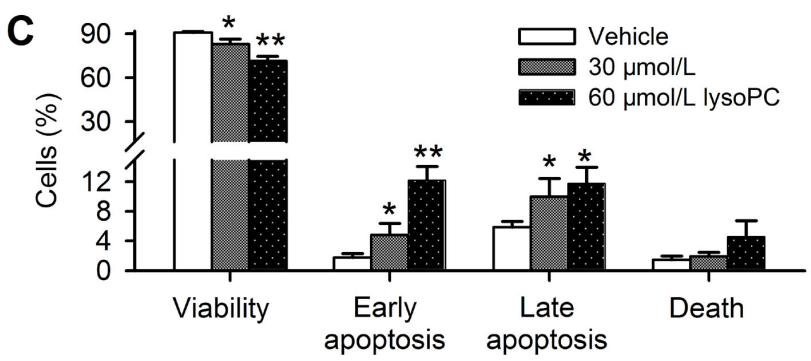

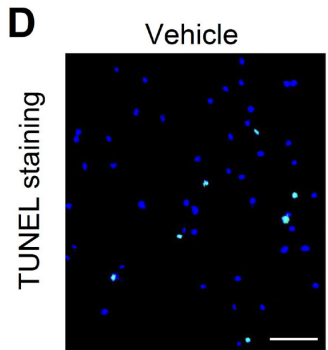

LysoPC $30 \mu \mathrm{mol} / \mathrm{L}$

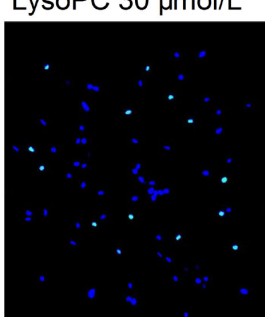

LysoPC $60 \mu \mathrm{mol} / \mathrm{L}$
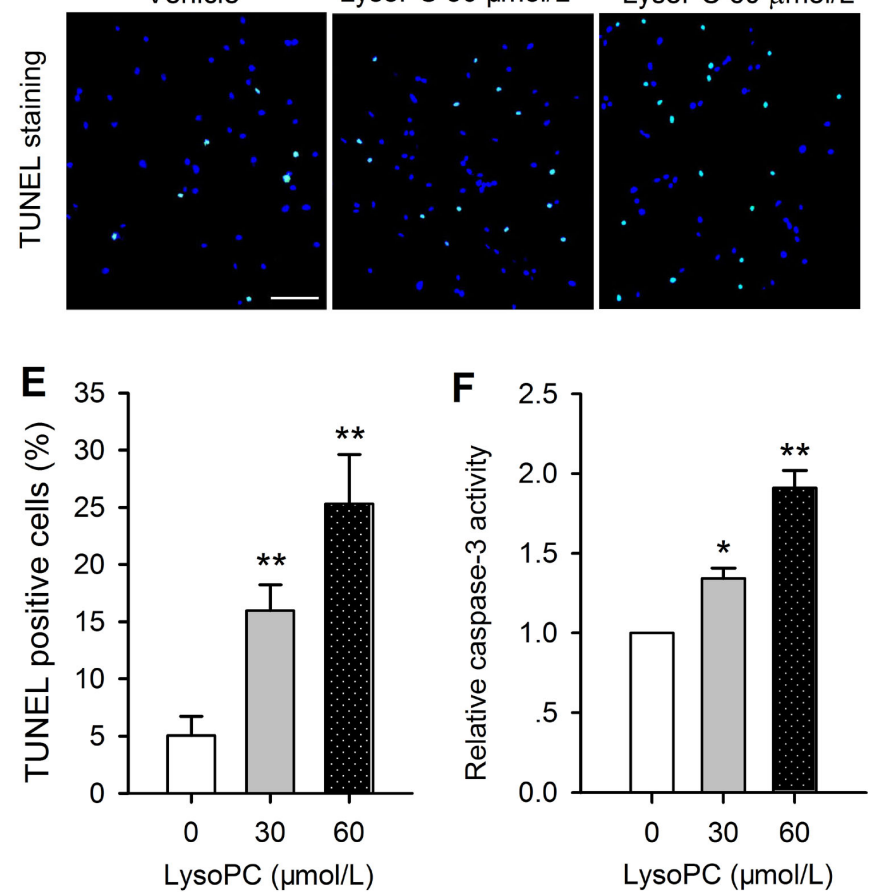

LysoPC $(\mu \mathrm{mol} / \mathrm{L})$

Figure 2: Flow cytometry analysis in cell treated with lysoPC. A. Cell cycling progression was not affected by 30 or $60 \mu \mathrm{mol} / \mathrm{L}$ lysoPC $(24 \mathrm{~h})$ in human coronary artery SMCs. B. Flow cytometry analysis was made in cells treated with $30 \mathrm{or} 60 \mu \mathrm{mol} / \mathrm{L}(24 \mathrm{~h})$ and co-stained with PI and Annexin V-FITC (V, viability; D, death; LA, late apoptosis; EA, early apoptosis) C. Percentage of cells that show viability, early apoptosis, late apoptosis and death after treatment with 30 or $60 \mu \mathrm{mol} / \mathrm{L}$ lysoPC $(n=3, * P<0.05, * * P<0.01 v s$. vehicle control). D. Representative microphotographs of TUNEL staining in human coronary artery SMCs treated with 30 or $60 \mu \mathrm{mol} / \mathrm{L}$ lysoPC (24 h). TUNEL labelling is stained in green and nuclei are labelled by DAPI staining in blue. Scale bar $=50 \mu \mathrm{m}$. E. The percentage of TUNELpositive cells in total cells. The DAPI staining cells were countered from five randomly picked regions $\left({ }^{* *} P<0.01\right.$ vs. vehicle control). F. Detection of the caspase-3 activity in human coronary artery SMCs treated with 30 or $60 \mu \mathrm{mol} / \mathrm{L}$ lysoPC for $24 \mathrm{~h}$. $(n=3$ individual experiments, ${ }^{*} P<0.05,{ }^{*} P<0.01$ vs. 0 , i.e. vehicle control). 
(Figure 4A). Interestingly, lysoPC-induced $\mathrm{Ca}^{2+}$ influx was prevented in human coronary artery SMCs by $\mathrm{LaCl}_{3}$ $(100 \mu \mathrm{mol} / \mathrm{L}, n=26, P<0.01 v s$. vehicle $)$, but not by nifedipine $(10 \mu \mathrm{mol} / \mathrm{L}, n=26)$ or KB-R7943 $(100 \mu \mathrm{mol} / \mathrm{L}$, $n=28)$. The ratio values of relative $\mathrm{Ca}^{2+}$ level at end of experiments are illustrated in right panel of Figure 4A. These results suggest that $\mathrm{Ca}^{2+}$ influx induced by lysoPC is through TRP channels, but not VGCC or NCX.

It is generally believed that TRPC and TRPV are the major subclasses of TRP channels that mediate $\mathrm{Ca}^{2+}$ influx [9]. The general TRPC channel blocker SKF-96365 [23], the specific TRPC3 blocker Pyr3 [24], the TRPV2 channel blocker ruthenium red $[25,26]$, and the TRPV4 blockers RN1734 [26] were therefore tested in human coronary artery SMCs. Figure 4B shows the effects of different TRP channel blockers on lysoPC-induced $\mathrm{Ca}^{2+}$ influx. LysoPCinduced $\mathrm{Ca}^{2+}{ }_{\mathrm{i}}$ increase was not affected in cells pretreated

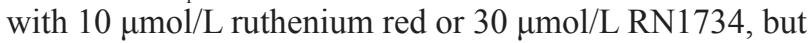
was clearly reduced in cells pretreated with $100 \mu \mathrm{mol} / \mathrm{L}$ SKF-96365 or $10 \mu \mathrm{mol} / \mathrm{L}$ Pyr3. The ratio values of relative $\mathrm{Ca}^{2+}$ levels at end of experiments are shown in the right panel of Figure 4B $(n=27-30, P<0.01 v s$. vehicle control). These results indicate that TRPC channels, but not TRPV2 or TRPV4 channels, are involved in lysoPCinduced $\mathrm{Ca}^{2+}$ influx in human coronary artery SMCs.

To determine whether blockade of TRPC channels would antagonize the apoptosis induced by lysoPC, cell viability (Figure S1A) was determined with MTT method in cells treated with lysoPC in the presence of TRPC channel blockers SKF96365 and Pyr3 (Figure S1A). SKF$96365(100 \mu \mathrm{mol} / \mathrm{L})$ and Pyr3 $(10 \mu \mathrm{mol} / \mathrm{L})$ significantly countered the increase of apoptosis and the decrease of cell viability induced by 30 or $60 \mu \mathrm{mol} / \mathrm{L}$ lysoPC $(n=3, P$ $<0.05$ vs. lysoPC alone). Flow cytometry was conducted to analyze human coronary artery SMCs treated with 60 $\mu \mathrm{mol} / \mathrm{L}$ lysoPC in the absence and presence of $100 \mu \mathrm{mol} / \mathrm{L}$ SKF-96365 or $10 \mu \mathrm{mol} / \mathrm{L}$ Pyr3 (24 h incubation) (Figure 4C). Figure 4D illustrates the mean percentage values of cell viability, early apoptosis, late apoptosis, and death. Pretreatment with $100 \mu \mathrm{mol} / \mathrm{L}$ SKF-96365 or $10 \mu \mathrm{mol} / \mathrm{L}$ Pyr3 significantly rescued lysoPC-induced decrease of cell viability and increase of early and late apoptosis $(n=3, P$ $<0.05$ or $P<0.01 v s$. vehicle). These results suggest that lysoPC-induced apoptosis is related to the activation of TRPC channels and $\mathrm{Ca}^{2+}$ influx.

\section{Effect of TRP channel blockade on apoptosis induced by lysoPC}

There are six tissue specific isoforms of TRPC channels in humans [16]. To demonstrate which specific isoforms are involved in lysoPC-induced $\mathrm{Ca}^{2+}$ influx and apoptosis, the gene expression of TRPC channels was initially determined with RT-PCR, and the channel proteins were then verified with Western blots in human coronary artery SMCs (Figure 5A). The genes and the proteins of TRPC1, TRPC3 and TRPC4 were evident, but not TRPC5, TRPC6, and TRPC7, in human coronary artery SMCs.

To investigate how these three types of TRPC channels mediate the lysoPC-induced $\mathrm{Ca}^{2+}$ influx and apoptosis in human coronary artery SMCs, siRNA molecules targeting TRPC1, TRPC3 or TRPC4 channels were transfected into human coronary artery SMCs. Figure 5B illustrates the Western blots of TRPC1, TRPC3 or TRPC4 channels in human coronary artery SMCs transfected with 20 or $50 \mathrm{nmol} / \mathrm{L}$ corresponding siRNAs. The relative protein levels of TRPC1, TRPC3 or TRPC4 were significantly reduced by silencing TRPC1, TRPC3 or TRPC4 gene $(n=3, P<0.05$ or $P<0.01 v s$. control siRNA or lipofectamine 2000).

The effect of lysoPC on $\mathrm{Ca}^{2+}{ }_{i}$ was further examined in human coronary artery SMCs transfected with 50 nmol/L corresponding siRNA. Figure 5C shows that the significant $\mathrm{Ca}^{2+}$ influx was not observed in cells with silenced TRPC1 or TRPC3 channels, while significant $\mathrm{Ca}^{2+}$ influx was seen in cells transfected with control siRNA or TRPC4 siRNA, and the ratio values of $\mathrm{Ca}^{2+}$ levels at end experiments in cells with transfecting siRNA molecules are shown in the right panel of Figure $5 \mathrm{C}(n=$ $28, P<0.01 v s$. control siRNA). These results indicate that TRPC1 or TRPC 3 channels, but not TRPC4 channels, are involved in lysoPC-induced $\mathrm{Ca}^{2+}$ influx. It should be noted that silencing either TRPC1 or TRPC3 diminished lysoPCinduced $\mathrm{Ca}^{2+}$ influx. This implies that the heterogeneous channel complex composed of both TRPC1 and TRPC3 subunits is likely involved in lysoPC-induced $\mathrm{Ca}^{2+}$ influx in human coronary artery SMCs.

\section{Interaction of TRPC1 and TRPC3}

The protein-protein interaction of TRPC1 and TRPC3 was determined by co-immunoprecipitation. Anti-TRPC1 or anti-TRPC3 was used to pull down TRPC1, TRPC3, or TRPC4 protein (Figure 5D). Coimmunoprecipitation revealed that the protein bands for TRPC1 and TRPC3 were observed at the expected molecular weight. The interaction protein bands of TRPC1 and TRPC3 were increased by lysoPC treatment (60 $\mu \mathrm{mol} / \mathrm{L}$ for $2 \mathrm{~min})$. No TRPC4 interaction bands were precipitated with TRPC1 or TRPC3. These results indicate that TRPC1 and TRPC3 subunits are interacted with each other to form TRPC1/TRPC3 channel complex, and mediate lysoPC-induced $\mathrm{Ca}^{2+}$ influx.

\section{Effects of silencing TRPC channels on cell viability and apoptosis induced by lysoPC}

LysoPC-induced apoptosis was further analyzed in human coronary artery SMCs with silencing TRPC1, 
A
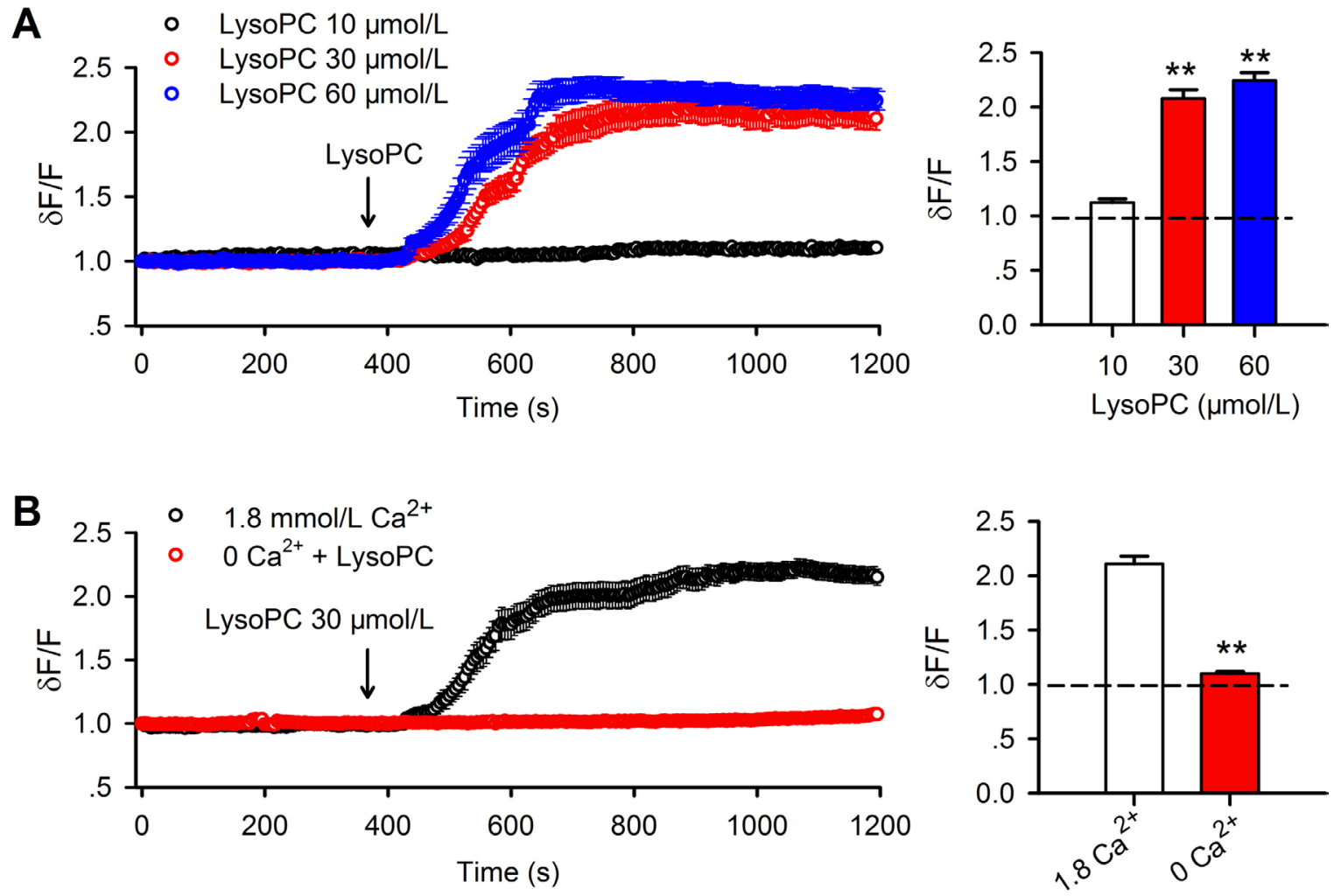

C

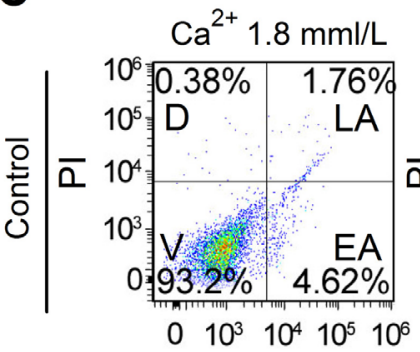

Annexin $\mathrm{V}$

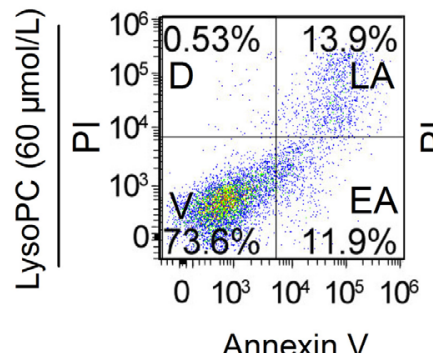

Annexin $\mathrm{V}$

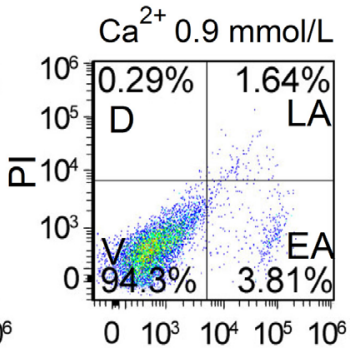

Annexin V

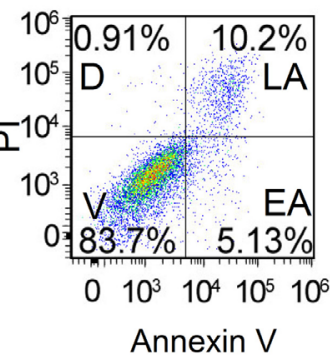

D
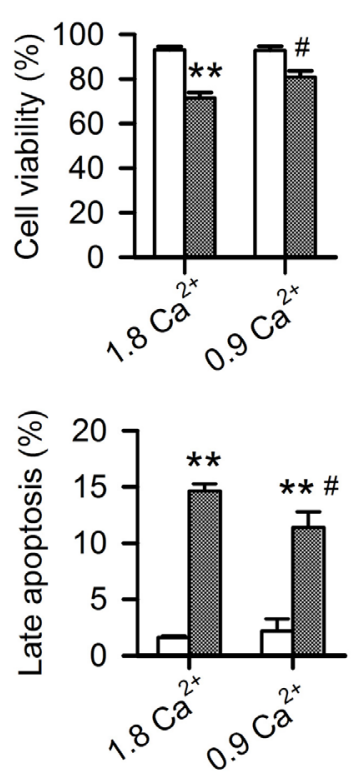

LysoPC $60 \mu \mathrm{mol} / \mathrm{L}$
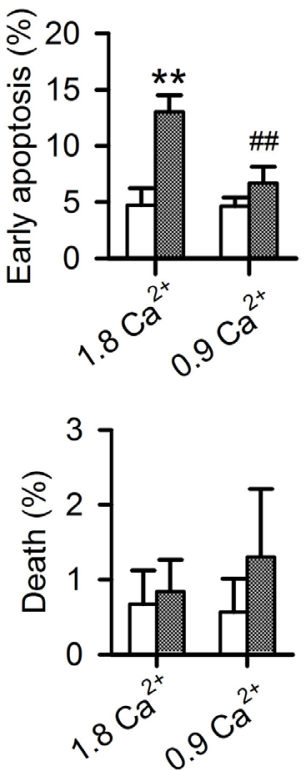

Figure 3: Effect of lysoPC on cytosolic $\mathbf{C a}^{2+}$. A. Cytosolic free $\mathrm{Ca}^{2+}$ was determined in Tyrode's solution containing $5 \% \mathrm{FBS}$ with a confocal microscopy technique in human coronary artery SMCs preloaded with Fluo-3 AM (data are mean $\pm \mathrm{SEM}$ ). The pseudoratio dF/F was applied to express intracellular free $\mathrm{Ca}^{2+}$ level, where $\mathrm{dF}$ is the measured fluorescence intensity of fluo 3 , and $\mathrm{F}$ is the initial level of fluorescence intensity. LysoPC $30 \mu \mathrm{mol} / \mathrm{L}(n=27)$ or $60 \mu \mathrm{mol} / \mathrm{L}(n=27, * * P<0.01 v s .10 \mu \mathrm{mol} / \mathrm{L}$ lysoPC), but not $10 \mu \mathrm{mol} / \mathrm{L}$ lysoPC $(n$ $=25)$, induced a significant sustained $\mathrm{Ca}^{2+}$ influx. B. LysoPC $(30 \mu \mathrm{mol} / \mathrm{L})$ induced sustained $\mathrm{Ca}^{2+}$ increase (data are mean $\left.\pm \mathrm{SEM}\right)$ in the presence of $1.8 \mathrm{mmol} / \mathrm{L} \mathrm{Ca}^{2+}$ in bath medium $(n=28)$, but not in the medium with $0 \mathrm{Ca}^{2+}$ and $1 \mathrm{mmol} / \mathrm{L} \mathrm{EGTA}(n=26, * * P<0.01 v s .1 .8$ $\mathrm{mmol} / \mathrm{L} \mathrm{Ca}^{2+}$ ). C. Cell apoptosis determined in 1.8 and $0.9 \mathrm{~mm} / \mathrm{L} \mathrm{Ca}^{2+}$ medium in human coronary artery SMCs by co-staining with PI and Annexin V-FITC (V, viability; D, death; LA, late apoptosis; EA, early apoptosis.) after treatment with $60 \mu \mathrm{mol} / \mathrm{L}$ lysoPC for $24 \mathrm{~h}$. D. Percent values of viability, early apoptosis, late apoptosis and death after treatment with $60 \mu \mathrm{mol} / \mathrm{L}$ lysoPC. $\left(n=3,{ }^{*} P<0.05, * * P<0.01\right.$ vs. vehicle control; $\# P<0.05, \# \# P<0.01$ vs. $1.8 \mathrm{mmol} / \mathrm{L} \mathrm{Ca}^{2+}$ ). 
TRPC3 or TRPC4. Cell viability was determined in human coronary artery SMCs transfected with $50 \mathrm{nmol} / \mathrm{L}$ corresponding siRNA. The viability (Figure S1B) was decreased in cells treated with 30 or $60 \mu \mathrm{mol} / \mathrm{L}$ lysoPC ( $n=3, P<0.01 v s$. control). LysoPC-induced reduction of cell viability was attenuated in cells with transfecting TRPC1 siRNA or TRPC3 siRNA $(n=3, P<0.05$ vs. control siRNA), but not TRPC4 siRNA. These results support the notion that TRPC1/TRPC3 channels, but not TRPC4, is involved in lysoPC-induced reduction of cell viability and apoptosis.

Then, a higher concentration of $60 \mu \mathrm{mol} / \mathrm{L}$ lysopC was chosen to treat the cells to obtain the significant changes in $24 \mathrm{~h}$ incubation for flow cytometry analysis.
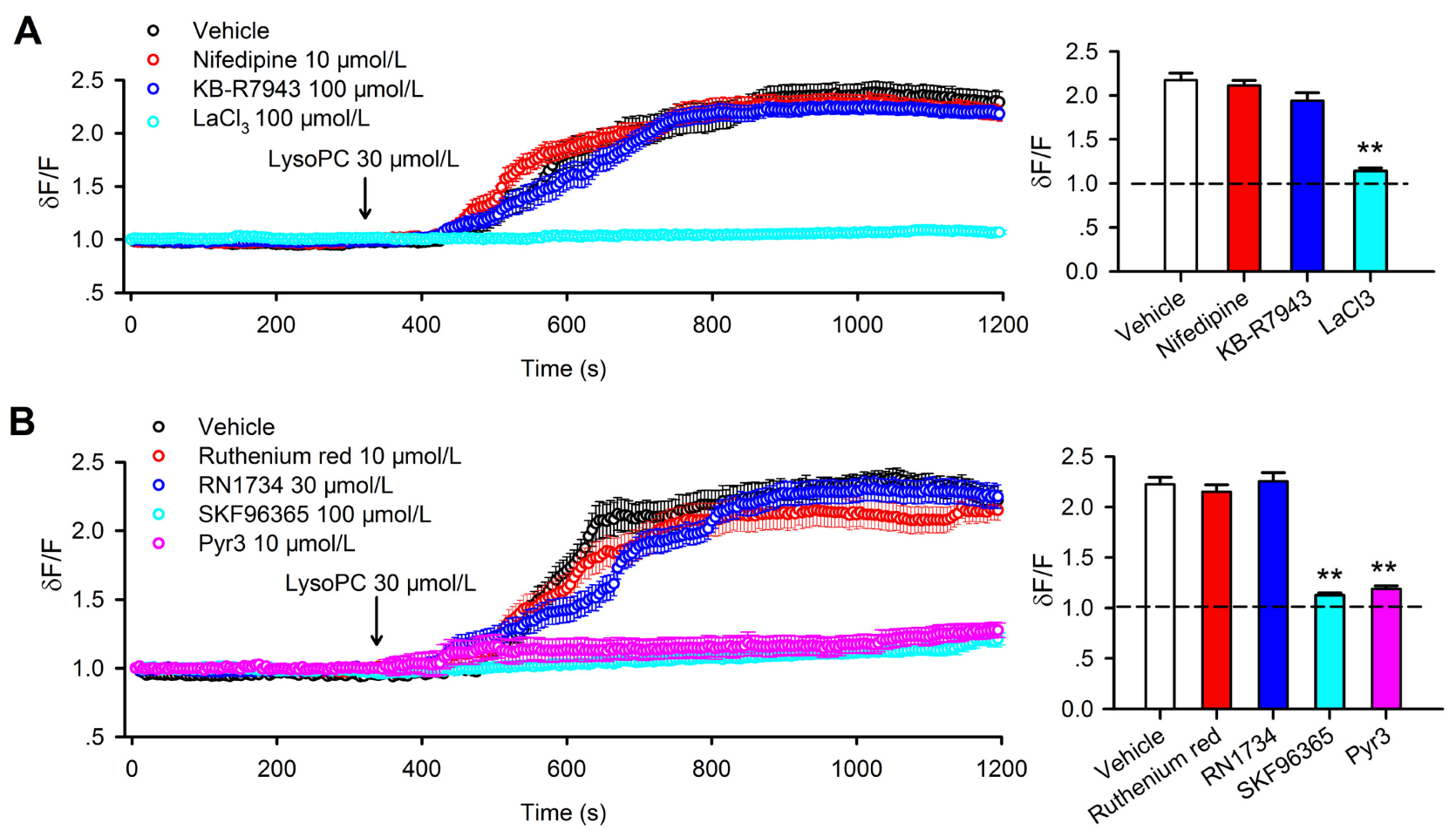

C

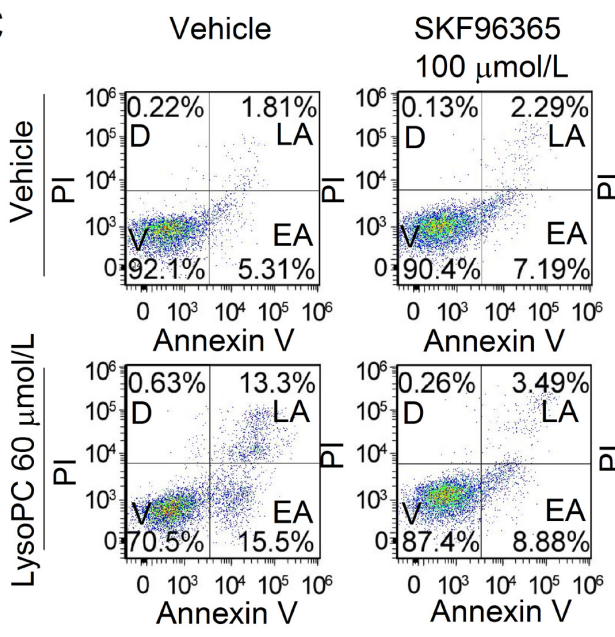

Pyr3 $10 \mu \mathrm{mol} / \mathrm{L}$
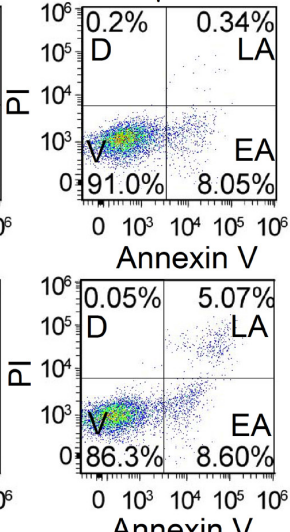

D $\square$ Vehicle
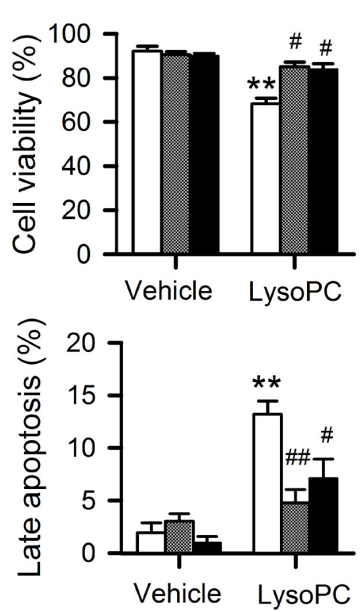
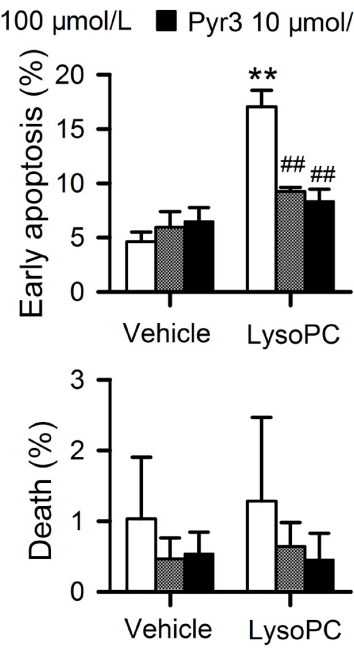

Figure 4: Effect of TRPC channel blockers on lysoPC-induced $\mathrm{Ca}^{2+}$ influx and apoptosis. A. Ca ${ }^{2+}$ influx induced by 30 $\mu \mathrm{mol} / \mathrm{L}$ lysoPC in cells pretreated with vehicle $(n=26), 10 \mu \mathrm{mol} / \mathrm{L}$ nifedipine $(n=26), 100 \mu \mathrm{mol} / \mathrm{L} \mathrm{KB}-\mathrm{R} 7943(n=26)$ or $100 \mu \mathrm{mol} / \mathrm{L}$ $\mathrm{LaCl}_{3}(n=26, * * P<0.01$ vs. vehicle $) \mathrm{B}$. $\mathrm{Ca}^{2+}$ influx induced by lysoPC in cells pretreated with vehicle $(n=27), 10 \mu \mathrm{mol} / \mathrm{L} \mathrm{Ruthenium}$ Red $(n=27), 30 \mu \mathrm{mol} / \mathrm{L}$ RN1734 $(n=27), 100 \mu \mathrm{mol} / \mathrm{L}$ SKF-96365 $(n=27, * * P<0.01 v s$. vehicle) or $10 \mu \mathrm{mol} / \mathrm{L}$ Pyr3 $(n=27, * * P<0.01$ $v s$. vehicle). C. Cell apoptosis was determined in cells treated with $60 \mu \mathrm{mol} / \mathrm{L}$ lysoPC in the absence (vehicle control) and presence of 100 $\mu \mathrm{mol} / \mathrm{L}$ SKF-96356 or $10 \mu \mathrm{mol} / \mathrm{L}$ Pyr3. D. Percent values of cell viability in cells treated with $60 \mu \mathrm{mol} / \mathrm{L}$ lysoPC in the absence (vehicle control) and presence of $100 \mu \mathrm{mol} / \mathrm{L}$ SKF-96356 or $10 \mu \mathrm{mol} / \mathrm{L}$ Pyr3 $(n=3$ individual experiments, $* * P<0.01$ vs. vehicle; $\# P<0.05, \# \# P$ $<0.01$ vs. lysoPC alone). 
Figure 6A shows the original graphs of apoptosis analysis with flow cytometry. Silencing TRPC1 or TRPC3, but not TRPC4, preserved cell viability in cells treated with 60 $\mu \mathrm{mol} / \mathrm{L}$ lysoPC. Figure $6 \mathrm{~B}$ illustrates the mean percentage values of cells that show viability, early apoptosis, late apoptosis, and death. LysoPC could decrease cell viability, and increase early and late apoptosis in cells transfected with control siRNA or TRPC4 siRNA $(n=3, P<0.05$ or $P<0.01 v s$. control siRNA), but not in cells transfected with TRPC1 siRNA or TRPC3 siRNA.

\section{Molecular signals involved in lysoPC-induced apoptosis}

Considered the importance of $\mathrm{Ca}^{2+}$ in lysoPCinduced apoptosis, the effects of lysoPC on apoptosisrelated proteins were determined in cells cultured with 1.8 and $0.9 \mathrm{mmol} / \mathrm{L}$ and treated with $60 \mu \mathrm{mol} / \mathrm{L}$ lysoPC for 3 and $6 \mathrm{~h}$. It was found that the pro-apoptotic proteins Bax and cleaved caspase- 3 were increased, whereas antiapoptotic protein $\mathrm{Bcl}-2$ and the survival kinase $\mathrm{p}$-Akt were reduced by lysoPC at $1.8 \mathrm{mmol} / \mathrm{L} \mathrm{Ca}^{2+}$, and the effects were attenuated at $0.9 \mathrm{mmol} / \mathrm{L}$ extracellular $\mathrm{Ca}^{2+}$ (Figure $7 \mathrm{~A}$ ). Figure $7 \mathrm{~B}$ illustrates the relative levels of $\mathrm{Bax}$, cleaved caspase-3, Bcl-2 and p-Akt. LysoPC $60 \mu \mathrm{mol} / \mathrm{L}$ incubation with $1.8 \mathrm{mmol} / \mathrm{L} \mathrm{Ca}^{2+}$ significantly increased the pro-apoptotic proteins Bax and cleaved caspase-3 ( $n$ $=3, P<0.05$ of $P<0.01 \mathrm{vs}$. vehicle) and decreased the anti-apoptotic protein Bcl-2 and the survival kinase p-Akt
( $n=3, P<0.05$ or $P<0.01 \mathrm{vs}$. vehicle), and the effects were attenuated in cells incubated with $0.9 \mathrm{mmol} / \mathrm{L} \mathrm{Ca}^{2+}$. Similar effects were observed for changes in apoptotic genes, which is determined using real time PCR in cells incubated with 1.8 or $0.9 \mathrm{mmol} / \mathrm{L} \mathrm{Ca}^{2+}$ (Figure S2A). These results suggest that lysoPC-induced apoptosis is related to the activation of pro-apoptotic kinases and the inhibition of anti-apoptotic and survival kinases, which is correlated to bath $\mathrm{Ca}^{2+}$ concentration.

These molecular signals involved in lysoPC-induced apoptosis were then determined in human coronary artery SMCs with silenced TRPC channels. It is interesting to note that $60 \mu \mathrm{mol} / \mathrm{L}$ lysoPC increased Bax and cleaved caspase-3, and decreased Bcl-2 and p-Akt in cells transfected with control siRNA or TRPC4 siRNA, but not with TRPC1 or TRPC3 (Figure 8A). Figure 8B illustrates the mean relative levels of Bax, cleaved caspase-3, Bcl-2 and p-Akt. Similar changes in the apoptotic genes detected using real time PCR (Figure S2B) were observed in human coronary artery SMCs transfected with TRPC1 siRNA or TRPC3 siRNA molecules. Silencing TRPC1 or TRPC3 significantly prevented the lysoPC-induced increase of the pro-apoptotic proteins/genes Bax and caspase- 3 and decrease of the anti-apoptotic protein/gene Bcl-2 and the survival kinase p-Akt in human coronary artery SMCs.

\section{DISCUSSION}

It is generally recognized that lysoPC derived from cell membrane phosphatidylcholine is an important cell
A
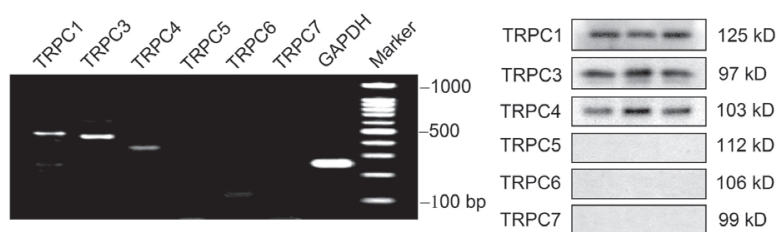

B
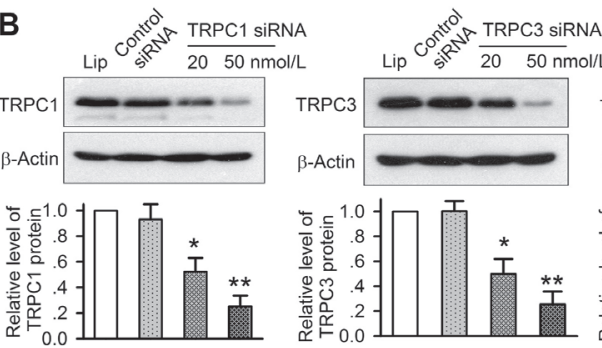

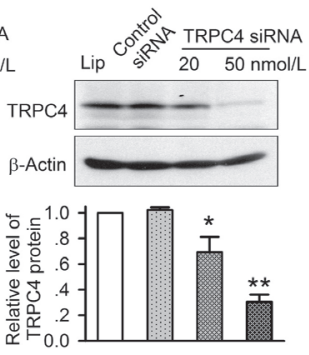

C
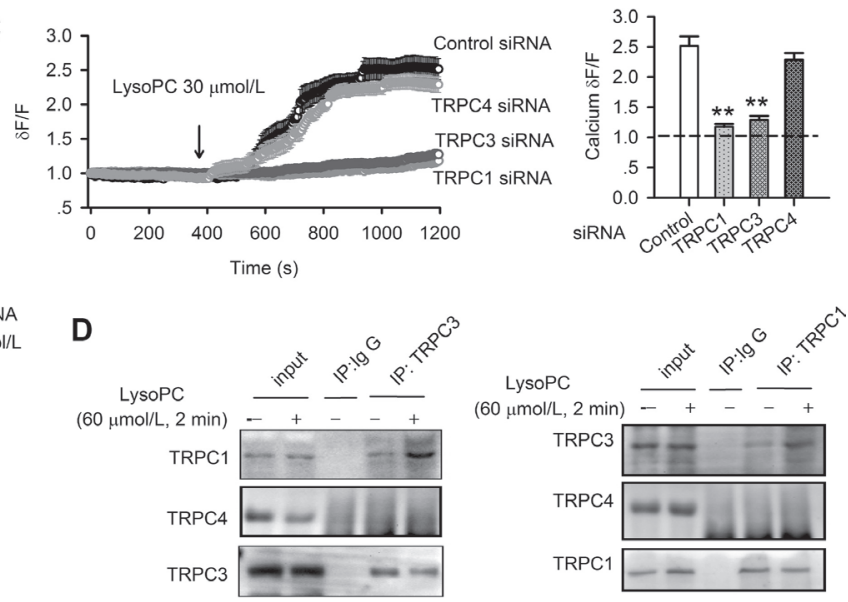

Figure 5: Silencing TRPC1, TRPC3 or TRPC4 channels and TRPC protein-protein interaction. A. RT-PCR (left) and Western blots (right) of TRPC isoforms in human coronary artery SMCs (passages 3, 4, and 6). B. Western blots and ratio of protein levels of TRPC1, TRPC3 or TRPC4 channels in human coronary artery SMCs transfected with 20 or $50 \mathrm{nmol} / \mathrm{L}$ siRNAs targeting TRPC1, TRPC3 or TRPC 4 channels (relative to b-actin and lipofectamine $2000, n=3$ individual experiments, ${ }^{*} P<0.05$, ${ }^{*} P<0.01 v s$. control siRNA or lipofectamine). C. $\mathrm{Ca}^{2+}$ influx (data are mean $\left.\pm \mathrm{SEM}\right)$ induced by $30 \mu \mathrm{mol} / \mathrm{L}$ lysoPC in cells transfected with $50 \mathrm{nmol} / \mathrm{L}$ control siRNA $(n$ $=27)$, TRPC1 siRNA $(n=27, * * P<0.01 v s$. control siRNA), TRPC3 siRNA $(n=28, * * P<0.01 v s$. control siRNA), or TRPC4 siRNA ( $n$ $=28$ ). D. Co-immunoprecipitation showing the interaction between TRPC 1 and TRPC3 proteins in cells treated without or with $60 \mu \mathrm{mol} / \mathrm{L}$ lysoPC. IP indicates the antibody used to pull down the interacting proteins. Ig G represents the negative control. 
A Control siRNA

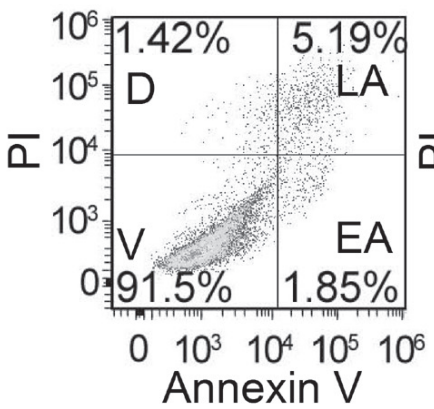

Control siRNA

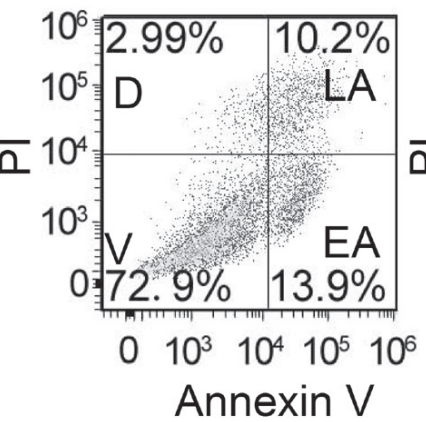

TRPC1 siRNA $1 0 ^ { 6 } \longdiv { 1 . 2 4 \% \quad 4 . 3 6 \% }$

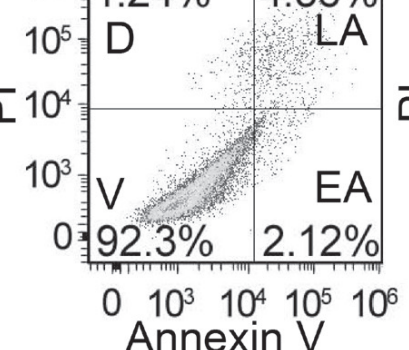

Annexin V

TRPC1 siRNA

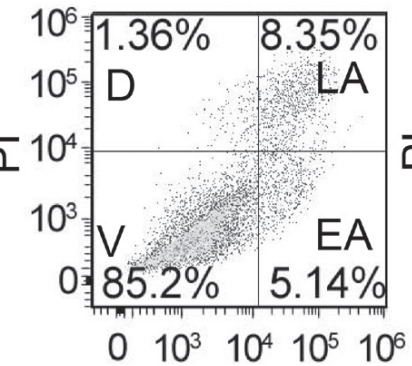

Annexin V
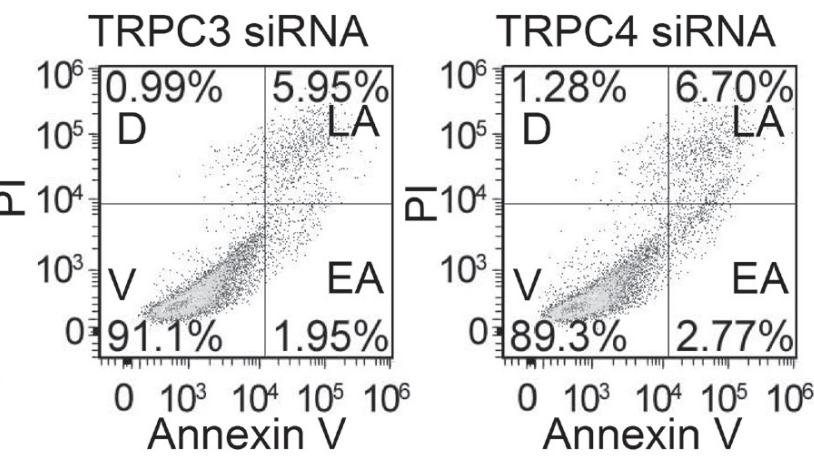

TRPC3 siRNA TRPC4 siRNA+lysoPC

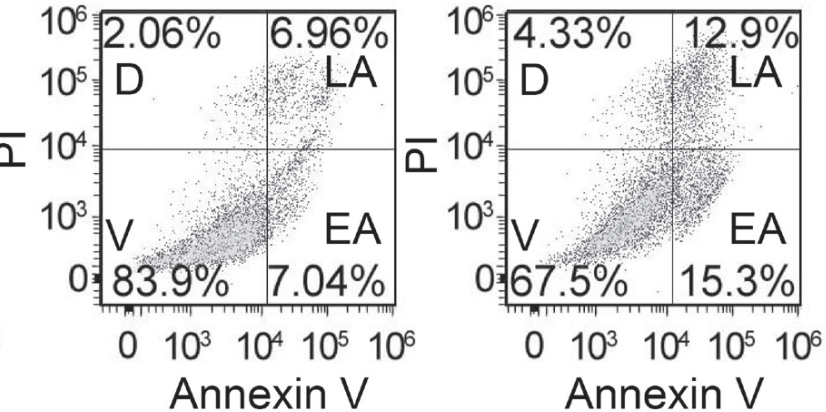

B
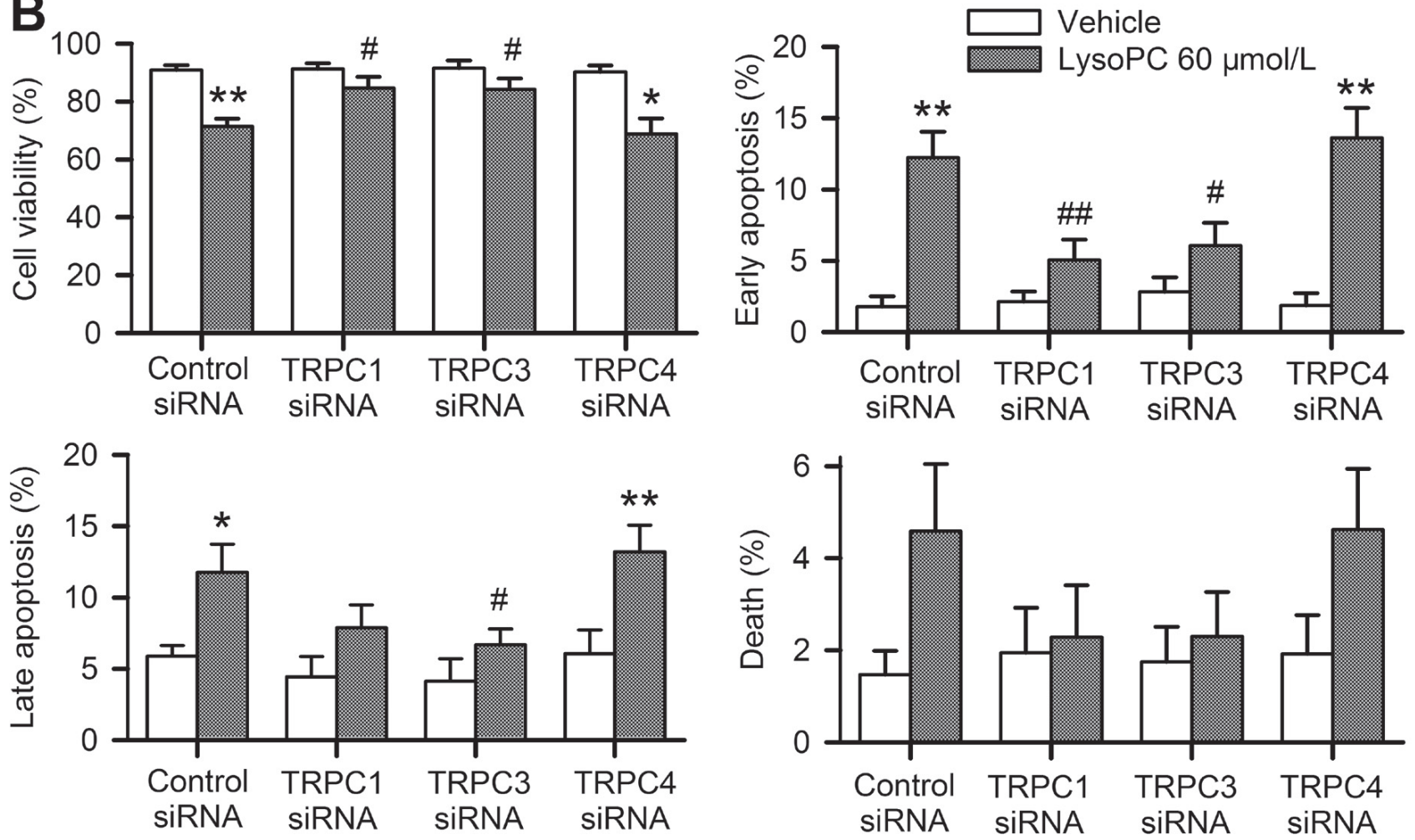

Figure 6: Effects of silencing TRPC channels on cell apoptosis. A. Flow cytometry analysis in cells transfected with $50 \mathrm{nM}$ control siRNA, TRPC1 siRNA, TRPC3 siRNA or TRPC4 siRNA for $72 \mathrm{~h}$ and stained with PI and Annexin V-FITC after incubating with vehicle (upper panel) or $60 \mu \mathrm{mol} / \mathrm{L}$ lysoPC (lower panel) for $24 \mathrm{~h}$ (V, viability; D, death; LA, late apoptosis; EA, early apoptosis). B. Percentage of cells showing viability, early apoptosis, late apoptosis, and death analyzed by flow cytometry. Data are mean \pm SEM $(n=3$, $* P<0.05, * * P<0.01$ vs. vehicle, $\# P<0.05$, \#\#P<0.01 vs. control siRNA with lysoPC). 
signaling molecule [27]. It is also a major phospholipid component of ox-LDL as a bioactive pro-inflammatory lipid generated by pathological activities. LysoPC exists in the blood plasma [28] at 140 and $150 \mu \mathrm{mol} / \mathrm{L}$ in free or bound form (with albumin) [29]. It has been reported that lysoPC is 5-fold higher in ox-LDL than in normal LDL [6]. LysoPC is therefore implicated as a critical factor in atherogenesis of ox-LDL $[3,4]$, and plays an important role in inflammatory disorders by altering various functions in a number of cell-types, including endothelial cells, SMCs, monocytes, macrophages, and T-cells [27]. LysoPC can be detected frequently in atherosclerotic lesions [30]. Although there is no doubt that lysoPC plays a role in atherogenesis, the detailed molecular mechanisms are not fully understood. An earlier study demonstrated that lysoPC increases $\mathrm{Ca}^{2+}{ }_{\mathrm{i}}$ via stimulating plateletactivating factor receptor in mouse macrophages, which correlates to the pathogenesis of atherosclerosis [31].

Actually, lysoPC-induced $\mathrm{Ca}^{2+}$ influx was described in cardiac myocytes early in two decades ago $[32,33]$. However, the potential pathways of lysoPC-induced $\mathrm{Ca}^{2+}$ influx are not fully understood. For instance, the reports whether L-type $\mathrm{Ca}^{2+}$ channel $\left(\mathrm{I}_{\mathrm{Ca.L}}\right)$ is involved in $\mathrm{Ca}^{2+}$ influx by lysoPC are controversial. Inhibition of $\mathrm{I}_{\mathrm{Ca.L}}$ by lysoPC was reported in guinea pig atrial [34] and ventricular myocytes [32], and increase of $\mathrm{I}_{\mathrm{Ca.L}}$ by lysoPC was observed in rat ventricular myocytes [35] and cultured rabbit portal vein smooth muscle cells [36]. On the other hand, L-type $\mathrm{Ca}^{2+}$ channel blocker verapamil significantly inhibited lysoPC-induced $\mathrm{Ca}^{2+}$ influx in Drosophila S2 cells [37], a very slight inhibition was observed in cultured coronary artery SMCs [13] and no inhibition was seen in check ventricular myocytes [33]. The discrepancy among these results may be related to differential types of cells and/or experimental conditions. The present observation and the previous report [38] support the notion that L-type $\mathrm{Ca}^{2+}$ channel is not involved in lysoPC-induced $\mathrm{Ca}^{2+}$ influx in human coronary artery SMCs, because the $\mathrm{Ca}^{2+}$ influx was not affected by the L-type $\mathrm{Ca}^{2+}$ channel blocker nifedipine.

Recent studies showed that lysoPC-induced increase of $\mathrm{Ca}^{2+}{ }_{i}$ is probably resulted from activation of TRP channels in human [38] and rabbit [13] coronary artery SMCs and in human endothelial cells [14, 39], which may participate in the atherogenesis [5-7]. However, it is not clear that the specific isoform(s) of TRP channels are involved. The present study demonstrates that TRPC1 and TRPC3 isoforms interact with each other to co-assembly form the heterogeneous channel complex in human coronary artery SMCs and mediate lysoPC-induced
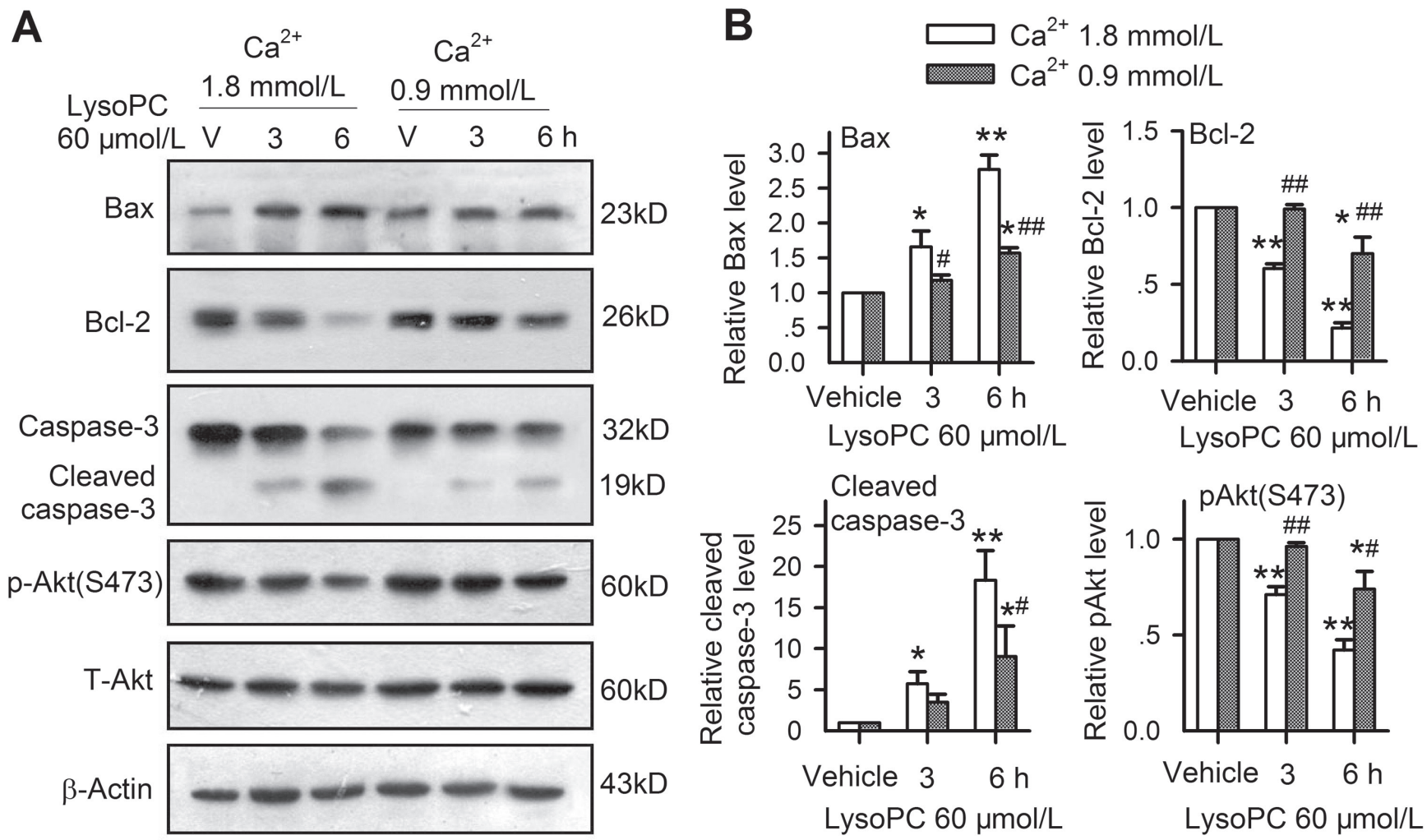

Figure 7: Intracellular signaling involved in apoptosis induced by lysoPC. A. Western blots of Bax, Bcl-2, caspase-3, and p-Akt(S473) in human coronary artery SMCs treated with $60 \mu \mathrm{mol} / \mathrm{L}$ lysoPC for $3 \mathrm{~h}$ or $6 \mathrm{~h}$ incubation with medium containing 1.8 or 0.9 $\mathrm{mmol} / \mathrm{L} \mathrm{Ca}^{2+}$. B. Relative ratio of Bax, Bcl-2, caspase-3, or p-Akt $\left(n=3,{ }^{*} P<0.05\right.$, ${ }^{* *} P<0.01$ vs. vehicle; $\# P<0.05$, \#\#P<0.01 vs.1.8 $\left.\mathrm{mmol} / \mathrm{L} \mathrm{Ca}^{2+}\right)$. 
A $\frac{\text { Control }}{3 \text { siRNA }} \times \frac{\text { TRPC1 siRNA }}{36} \vee \frac{\text { TRPC3 siRNA }}{36} \vee \frac{\text { TRPC4 siRNA }}{36 \mathrm{~h}}$

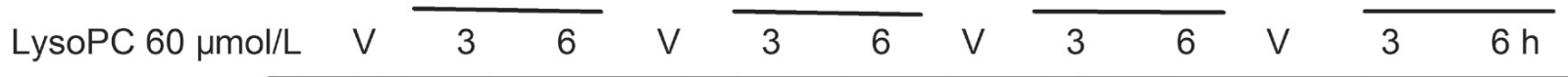

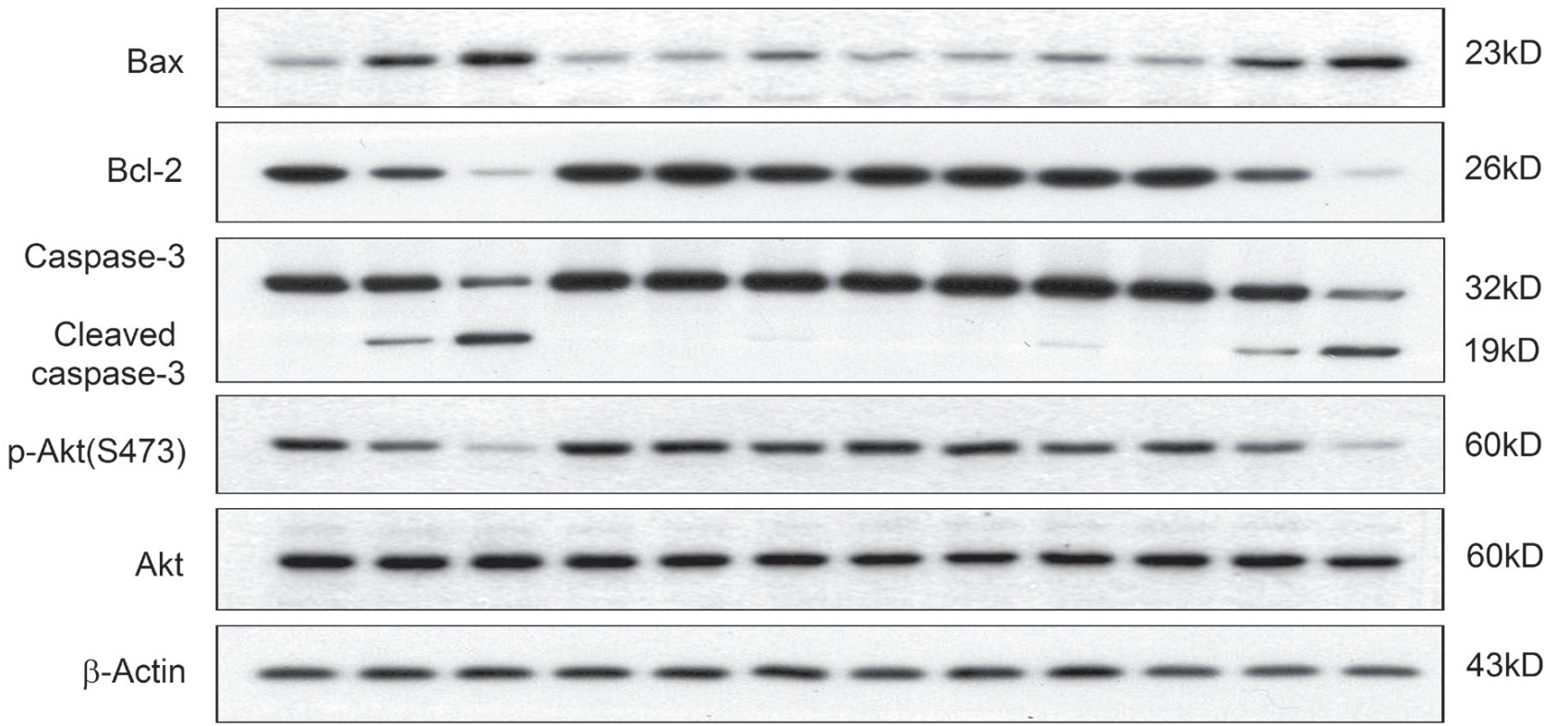

B
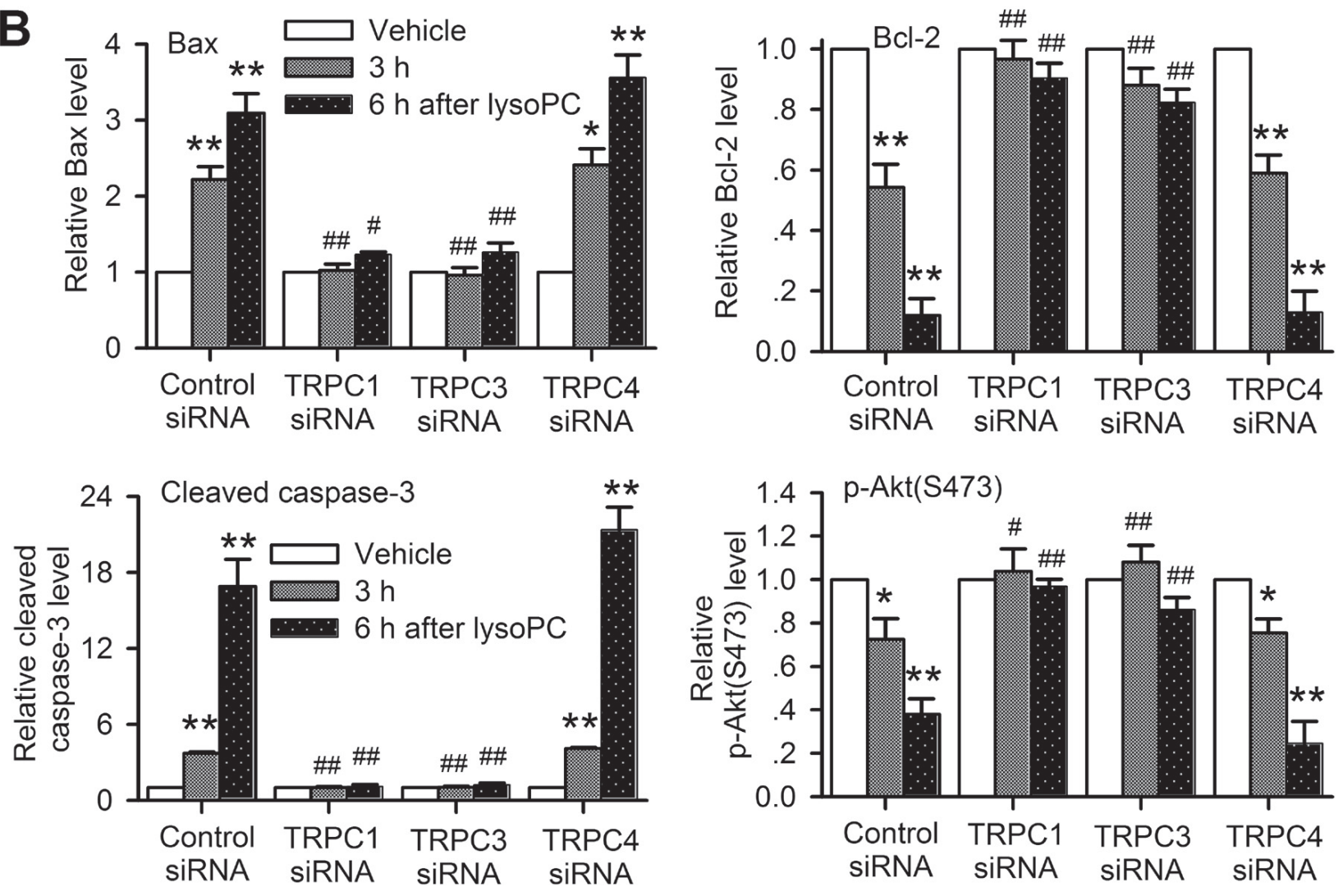

Figure 8: TRPC channels are involved in apoptotic signaling induced by lysoPC. A. Western blots of Bax, Bcl-2, caspase-3, and p-Akt in human coronary artery SMCs transfected with $50 \mathrm{nM}$ control siRNA, TRPC1 siRNA, TRPC3 siRNA or TRPC4 siRNA for $72 \mathrm{~h}$, and then treated with vehicle $(\mathrm{V})$ or $60 \mu \mathrm{mol} / \mathrm{L}$ lysoPC for 3 and $6 \mathrm{~h}$. B. Relative mean levels of Bax, Bcl-2, caspase-3, and p-Akt in human coronary artery SMCs with the same treatment as in $\mathrm{A}\left(n=3,{ }^{*} P<0.05,{ }^{*} P<0.01\right.$ vs. vehicle, $\# P<0.05, \# \# P<0.01$ vs. control siRNA). 
$\mathrm{Ca}^{2+}$ influx, thereby cause apoptosis via activating the pro-apoptotic proteins Bax and cleaved caspase- 3 and inhibiting the anti-apoptotic protein Bcl-2 and the survival kinase p-Akt. Silencing TRPC1 or TRPC3 isoform diminishes the $\mathrm{Ca}^{2+}$ influx and inhibits the lysoPC-induced apoptosis.

It has been well documented that cytosolic $\mathrm{Ca}^{2+}$ is a key regulator of cellular biology, physiology and pathophysiology [9]. Cellular $\mathrm{Ca}^{2+}$ overload is highly toxic, and severe $\mathrm{Ca}^{2+}$ dysregulation can promote cell death directly through necrosis, while a more controlled cytosolic $\mathrm{Ca}^{2+}$ increase induced by milder insults promotes cell death through apoptosis [40]. The present study demonstrated that TRPC1/TRPC3 channels mediate lysoPC-induced $\mathrm{Ca}^{2+}$ influx and decrease cell viability. The reduction of cell viability by lysoPC is mainly resulted from apoptosis, suggesting that $\mathrm{Ca}^{2+}$ influx by lysoPC via activating TRPC1/TRPC3 channels is a milder insult in human coronary artery SMCs. Therefore, although $\mathrm{Ca}^{2+}$ influx induced by lysoPC was observed in seconds to minutes, a $24 \mathrm{~h}$ incubation was required for significant effect on cell viability and apoptosis.

It is recognized that apoptosis of vascular SMCs plays an important role in generating human vascular disorders including restenosis after angioplasty, low levels of atherosclerotic plaques and vessel remodeling [41-43]. $\mathrm{Ca}^{2+}$ overloading is critically responsible for the apoptosis, and blockade of $\mathrm{Ca}^{2+}$ influx is an effective way to prevent atherogenesis $[44,45]$. $\mathrm{Ca}^{2+}$-induced apoptosis is usually involved in Bcl-2 family proteins [46]. LysoPC-induced apoptosis was found mainly at early and late stages of apoptotic pathway, which is consistent with earlier reports that increase in cytosolic $\mathrm{Ca}^{2+}$ occurs at early and late stages of the apoptotic pathway $[47,48]$. In this study, we also observed that lysoPC significantly decreased the antiapoptotic protein $\mathrm{Bcl}-2$ and increased the pro-apoptotic proteins $\mathrm{Bax}$ and cleaved caspase- 3 in human coronary artery SMCs upon the $\mathrm{Ca}^{2+}$ influx. In addition, lysoPCinduced p-Akt reduction was also involved in vascular apoptosis by increasing $\mathrm{Ca}^{2+}$ influx via activating TRPC1/ TRPC3 channels. This is consistent with a recent report in which Akt1 activation inhibits vascular SMC apoptosis during atherogenesis [43].

In the hearts, it is believed that TRPC channels mediate pathologic cardiac hypertrophy via increasing $\mathrm{Ca}^{2+}$ influx [49]. TRPC1/TRPC4 channel complexdependent $\mathrm{Ca}^{2+}$ cycling was observed in adult cardiomyocytes. A background $\mathrm{Ca}^{2+}$ entry pathway mediated by TRPC1/TRPC4 channels is critical for development of pathological cardiac remodeling [50]. The present study demonstrated that lysoPC-induced $\mathrm{Ca}^{2+}$ influx was related to activation of TRPC1/TRPC3 channels; thereafter apoptosis process was initiated in cultured human coronary artery SMCs. Three lines of evidence support the conclusion that TRPC1 and TRPC3 together form $\mathrm{Ca}^{2+}$ entry channels and mediate apoptosis induced by lysoPC in this study. First, the general TRPC channel blocker SKF-96365 or the TRPC3 inhibitor Pyr3 decreased the $\mathrm{Ca}^{2+}$ influx and the reduced cell viability induced by lysoPC. Second, silencing TRPC1 or TRPC3 isoform abolished lysoPC-induced $\mathrm{Ca}^{2+}$ influx and apoptosis. Third, lysoPC-induced increase of the proapoptotic proteins Bax and cleaved caspase- 3 and decrease of the anti-apoptotic protein Bcl-2 and the survival kinase p-Akt were not observed in cells with silencing TRPC1 or TRPC3.

Collectively, the present study provides the novel information that lypoPC induces $\mathrm{Ca}^{2+}$ influx as well as apoptosis by activating TRPC1/TRPC3 channels in human coronary artery SMCs, which may be involved in atherogenesis in humans. The future effort is required to investigate whether selective TRPC1/TRPC3 channel blockers can be clinically used for treating atherosclerosis in patients with high ox-LDL.

\section{METERIALS AND METHODS}

\section{Human coronary artery SMCs}

The primary human coronary artery SMCs were purchased from ScienCell Research Laboratories (Carlsbad, CA, USA) and cultured in $\alpha$-MEM/F12 (Invitrogen, Hong Kong, China). The media were supplemented with $10 \%$ fetal bovine serum, $100 \mathrm{IU}$ penicillin and $100 \mu \mathrm{g} / \mathrm{mL}$ streptomycin (Invitrogen). The cells from 3-8 passages were used for the experiments.

\section{Reagents and antibodies}

LysoPC (\#L1381), 3-(4,5-dimethylthiazol-2-yl)-2,5diphenyltetrazolium bromide (MTT, \#M2128), nifedipine (\#7634), KB-R7943 (\#K4144), LaCl3 (\#449830), ruthenium red (\#R2751), RN1734 (\#0658), SKF96365 (\#S7809) and Pyr3 (\#P0032) were obtained from SigmaAldrich (St. Louis, MO, USA). The primary antibodies anti-TRPC1 (sc-133076), anti-TRPC3 (sc-514670), antiTRPC4 (sc-15063), anti-TRPC5 (sc-18737), anti-Bax (sc-6236), and anti-Bcl-2 (sc-7382) were purchased from Santa Cruz Biotechnology (Santa Cruz, CA, USA). AntiTRPC6 (BA3394), anti-TRPC7 (PB0272) were purchased from Boster Biotechnology (Wuhan, China). Anticaspase-3 (\#9662), anti-Akt (\#9272) and anti-pAkt(S473) (\#4060) were from Cell Signaling Technology (Danvers, MA, USA). S-MEM without $\mathrm{Ca}^{2+}$ medium (\#11380037) were obtained from Gibco. Other reagents were described as in specified. 


\section{Cell viability assay}

The cell viability was determined with MTT assay as described previously $[51,52]$. Briefly, human coronary artery SMCs were seeded in 96-well plates (Thermo Fisher Scientific, MA, USA) for $24 \mathrm{~h}$ and incubated with medium containing 5\% FBS and different concentrations of lypoPC or equal volume of vehicle (ethanol, SigmaAldrich) for different period of time. The cells were then incubated with $0.5 \mathrm{mg} / \mathrm{mL}$ MTT for $3 \mathrm{~h}$, and re-suspended in $150 \mu \mathrm{L}$ of DMSO. Absorbance was measured at 575 nm using FLUOstar Omega (BMG Labtech's, Germany). The cells treated with DMSO were considered to be $100 \%$ viable.

\section{Flow cytometry analysis}

Flow cytometric analysis $[51,52]$ was used to determine cell cycling progression and apoptosis. The cell cycling progression was determined in human coronary artery SMCs incubated with medium containing 5\% FBS lypoPC at 30 or $60 \mu \mathrm{mol} / \mathrm{L}$ for $24 \mathrm{~h}$. The cells were harvested and fixed in $70 \%$ cold methanol overnight at $4{ }^{\circ} \mathrm{C}$ and then treated with RNase $\mathrm{A}$ and exposed to propidium iodide (PI) (Invitrogen) for $30 \mathrm{~min}$ at room temperature. The cell cycle data of flow cytometry were analyzed by FlowJo software (Ashland, OR, USA).

The apoptosis assay was made in human coronary artery SMCs harvested by EDTA-free trypsin. The cells were washed with PBS and then incubated at $4^{\circ} \mathrm{C}$ in a binding buffer $(100 \mu \mathrm{L})$ containing $5 \mathrm{mg}$ of propidium iodide and $5 \mu \mathrm{L}$ of Annexin V-FITC (R\&D Systems, Minneapolis, MN, USA) in the dark for 15 min. Afterwards, $900 \mu \mathrm{L}$ binding buffer was added and fluorescence of Annexin V-FITC and propidium iodide were detected by Gallios Flow Cytometer (Beckman, USA) and data were analyzed with FlowJo software. Cells positive for Annexin V-FITC were considered to be apoptotic whereas cells positive for PI and negative for FITC-Annexin V were to be considered death.

\section{TUNEL assay}

The TUNEL (terminal deoxynucleotidyl transferase dUTP nick end labeling kit from Beyotime Institute of Biotechnology (Shanghai, China) was employed to detect DNA fragmentation resulted from apoptosis following manufacturer's instruction. The human coronary artery SMCs were seeded on the coverslips and incubated in the culture medium containing 5\% FBS lypoPC (30 or $60 \mu \mathrm{mol} / \mathrm{L}$ ) for $24 \mathrm{~h}$. The cells were fixed with $4 \%$ paraformaldehyde for $20 \mathrm{~min}$ after incubation of PBS with $0.2 \%$ Triton X-100 for $5 \mathrm{~min}$. The cells were then treated with the mixture of terminal deoxynucleotidyl transferase enzyme, terminal deoxynucleotidyl transferase reaction buffer and fluorescent labeling buffer $(1: 24: 25)$ at $37^{\circ} \mathrm{C}$ for $60 \mathrm{~min}$. DAPI staining were used to count total cell number and the apoptotic cells with green nuclei. The apoptotic cells were quantitated by counting the number of TUNEL-positive cells in four microscopic fields randomly.

\section{Caspase-3 activity assay}

Caspase-3 activity kit from Beyotime Institute of Biotechnology was used following manufacturer's instructions. Briefly, human coronary artery SMCs with different treatments were harvested, rinsed with PBS, resuspended in lysis buffer, and then incubated on ice for $15 \mathrm{~min}$. The lysate was centrifuged at $16,000 \mathrm{~g}$ at $4^{\circ} \mathrm{C}$ for $15 \mathrm{~min}$. Approximately $70 \mu \mathrm{L}$ of reaction buffer and $10 \mu \mathrm{L}$ of caspase-3 substrate were mixed with $20 \mu \mathrm{L}$ lysate supernatant, and then incubated in 96-well plates at $37^{\circ} \mathrm{C}$ for $4 \mathrm{~h}$. Absorbance was measured at $405 \mathrm{~nm}$ using FLUOstar Omega (BMG LABTECH Inc., Cary, NC, USA). The caspase-3 activity was described as a percentage of control.

\section{$\mathrm{Ca}^{2+}{ }_{\mathrm{i}}$ measurement}

$\mathrm{Ca}^{2+}{ }_{i}$ in human coronary artery SMCs was determined with a confocal laser scanning microscope (Olympus FV300, Tokyo, Japan) as described previously [53]. Briefly, the cells were cultured in a $35 \mathrm{~mm}$ dish (Thermo Fisher Scientific, MA, USA) for $48 \mathrm{~h}$ and then loaded with $5 \mu \mathrm{mol} / \mathrm{L}$ fluo-3 AM (Biotium, Hayward, CA, USA) for $30 \mathrm{~min}$ at $37^{\circ} \mathrm{C}$, incubated in serum-free bath solution for $40 \mathrm{~min}$ in the dark, and then washed with bath solution. The bath solution contains (in $\mathrm{mmol} / \mathrm{L}$ ) $\mathrm{NaCl} 140, \mathrm{KCl} 5.0, \mathrm{MgCl} 21.0, \mathrm{CaCl} 21.8$, HEPES 10, glucose 10 (pH adjusted to 7.3 using $\mathrm{NaOH}$ ), and 5\% FBS. Fluorescence was excited by an argon laser at $488 \mathrm{~nm}$ and emission was detected at $525 \mathrm{~nm}$. The $\mathrm{Ca}^{2+}{ }_{i}$ level was expressed as ratio of basal fluorescence intensity.

\section{Messenger RNA measurement}

Messenger RNAs of TRPC channels were determined in human coronary artery SMCs with reversetranscription polymerase chain reaction (RT-PCR) as described previously [54]. Briefly, total RNA from cells was extracted using TriZol (Invitrogen) according to the manufacturer's instructions, and cDNA was generated with Primescript RT reagent kit (Takara, Dalian, China) and used as a template for the amplification using our previously designed TRPC primers [51, 52]. Real-time PCR (Applied Biosystems StepOnePlus ${ }^{\mathrm{TM}}$ ) was used to determine apoptosis-related genes in human coronary artery SMCs treated with lysoPC using SYBR Green 
qPCR Kit (Thermo Fisher Scientific, MA, USA) with primers as described previously [55]. Alterations in relative gene expression were determined by the DDCT method.

\section{Western blotting analysis and co- immunoprecipitation}

The membrane proteins were determined with Western immunoblotting analysis as described previously. Briefly, cells were lysed with modified RIPA buffer (50 $\mathrm{mmol} / \mathrm{L}$ Tris-Cl, $\mathrm{pH} 8,150 \mathrm{mmol} / \mathrm{L} \mathrm{NaCl}, 1 \%$ Nonidet P-40 (NP-40), 0.5\% sodium deoxycholate, 1\% SDS) for $30 \mathrm{~min}$ at $4^{\circ} \mathrm{C}$, cell lysates were then centrifuged at $12,000 \mathrm{~g}$ for $15 \mathrm{~min}$ at $4^{\circ} \mathrm{C}$. After transferring the supernatant to a fresh ice-cold tube, protein concentration was determined with Bio-Rad protein assay. Equal concentrations of proteins were mixed with SDS sample buffer and denatured at $95^{\circ} \mathrm{C}$ for $5 \mathrm{~min}$. Samples were resolved with $8 \%$ SDS-page gel. Gels were then transferred onto nitrocellulose membrane paper, and membranes were blocked with $5 \%$ non-fat dried milk in TTBS $(0.1 \%$ Tween-20) for $1 \mathrm{~h}$. After blocking, the blots were incubated overnight at $4{ }^{\circ} \mathrm{C}$ in corresponding primary antibodies (1:1000-2000). After washing with TTBS, the membranes were incubated with HRP-conjugated secondary antibodies $(1: 5,000)$ (Santa Cruz Biotech) at room temperature for $1 \mathrm{~h}$. Membranes were washed again with TTBS then processed to develop x-ray film using an enhanced chemiluminescence detection system (ECL; GE Healthcare, Bio-Science AB, Uppsala, Sweden). The relative band intensities were measured by image analysis software Gel-Pro Analyzer.

Co-immunoprecipitation was used to determine protein-protein interaction as described previously $[51,52]$. Briefly, the cultured human coronary artery SMCs were treated with or without lysoPC for $2 \mathrm{~min}$ before the harvest. Then, equal amounts of proteins were immunoprecipitated with $2 \mu \mathrm{g}$ of antibody at $4{ }^{\circ} \mathrm{C}$ overnight. Then, $20 \mu \mathrm{L}$ of protein $\mathrm{A} / \mathrm{G}$ agarose beads (Santa Cruz Biotech) was added and incubate for $2 \sim 4 \mathrm{~h}$ at $4{ }^{\circ} \mathrm{C}$. Immunoprecipitated proteins bound to the pelleted protein $\mathrm{A} / \mathrm{G}$ beads were washed thoroughly in PBS, denatured in Laemmli sample buffer, electrophoresed and blotted. Proteins were detected by using anti-TRPC1 and anti-TRPC 3 primary antibody, respectively. As a negative control, protein samples were mock-immunoprecipitated with pre-immuno-IgG and treated in the same way.

\section{RNA interference}

Small interfering RNA (siRNA) molecules targeting human TRPC1 (sc-42664), TRPC3 (sc-42666), TRPC4 (sc-42668), and negative control (sc-37007) were purchased from Santa Cruz Biotech. These siRNAs are target-specific 19-25nt siRNA designed to knock down gene expression with the procedure described previously [56]. Human coronary artery SMCs at $60 \sim 70 \%$ confluence were transfected with siRNA molecules at 20 or 50 $\mathrm{nmol} / \mathrm{L}$ using lipofectamine 2000 (Invitrogen). $72 \mathrm{~h}$ after transfection, cells were used for determining $\mathrm{Ca}^{2+}$ activity, related gene and protein expression, and cell proliferation and apoptosis assays.

\section{Statistical analysis}

Data are expressed as mean \pm SEM, and statistical differences between groups were further evaluated by Student's t-test two group comparison or two-way ANOVA for multiple groups. Differences of $P<0.05$ were considered to be significant.

\section{ACKNOWLEDGMENTS}

This study was supported in part by a grant (31401177) from National Natural Science Fund of China, grants (2014M551841 and 2015T80681) from China Postdoctoral Science Foundation, a grant (3502Z20144059) and a Key Cardiovascular Laboratory Fund (3502Z20150050) from Department of Xiamen Science and Technology, Xiamen, Fujian, China.

\section{CONFLICTS OF INTEREST}

None declared.

\section{REFERENCES}

1. Sprague $\mathrm{AH}$ and Khalil RA. Inflammatory cytokines in vascular dysfunction and vascular disease. Biochem Pharmacol. 2009; 78:539-552.

2. Doran AC, Meller N and McNamara CA. Role of smooth muscle cells in the initiation and early progression of atherosclerosis. Arterioscler Thromb Vasc Biol. 2008; 28:812-819.

3. Matsumoto $\mathrm{T}$, Kobayashi $\mathrm{T}$ and Kamata K. Role of lysophosphatidylcholine (LPC) in atherosclerosis. Curr Med Chem. 2007; 14:3209-3220.

4. Matsubara $\mathrm{M}$ and Hasegawa K. Benidipine, a dihydropyridine-calcium channel blocker, prevents lysophosphatidylcholine-induced injury and reactive oxygen species production in human aortic endothelial cells. Atherosclerosis. 2005; 178:57-66.

5. Kougias P, Chai H, Lin PH, Lumsden AB, Yao Q and Chen C. Lysophosphatidylcholine and secretory phospholipase A2 in vascular disease: mediators of endothelial dysfunction and atherosclerosis. Med Sci Monit. 2006; 12:RA5-16.

6. Heermeier K, Schneider R, Heinloth A, Wanner C, Dimmeler $\mathrm{S}$ and Galle J. Oxidative stress mediates 
apoptosis induced by oxidized low-density lipoprotein and oxidized lipoprotein(a). Kidney Int. 1999; 56:1310-1312.

7. Dohi T, Miyauchi K, Ohkawa R, Nakamura K, Kurano M, Kishimoto T, Yanagisawa N, Ogita M, Miyazaki T, Nishino A, Yaginuma K, Tamura H, Kojima T, Yokoyama K, Kurata T, Shimada K, et al. Increased lysophosphatidic acid levels in culprit coronary arteries of patients with acute coronary syndrome. Atherosclerosis. 2013; 229:192-197.

8. Berridge MJ, Bootman MD and Roderick HL. Calcium signalling: dynamics, homeostasis and remodelling. Nat Rev Mol Cell Biol. 2003; 4:517-529.

9. Clapham DE. Calcium signaling. Cell. 2007; 131:10471058.

10. Borahay MA, Kilic GS, Yallampalli C, Snyder RR, Hankins GD, Al-Hendy A and Boehning D. Simvastatin Potently Induces Calcium-Dependent Apoptosis of Human Leiomyoma Cells. J Biol Chem. 2014; 289:35075-86

11. Fernandez-Velasco M, Ruiz-Hurtado G, Gomez AM and Rueda A. Ca handling alterations and vascular dysfunction in diabetes. Cell Calcium. 2014; 56:397-407.

12. Tanaka T, Ikeda K, Yamamoto Y, Iida H, Kikuchi H, Morita T, Yamasoba T, Nagai R and Nakajima T. Effects of serum amyloid a and lysophosphatidylcholine on intracellular calcium concentration in human coronary artery smooth muscle cells. Int Heart J. 2011; 52:185-193.

13. Terasawa K, Nakajima T, Iida $H$, Iwasawa $K$, Oonuma $H$, Jo T, Morita T, Nakamura F, Fujimori Y, Toyo-oka T and Nagai R. Nonselective cation currents regulate membrane potential of rabbit coronary arterial cell: modulation by lysophosphatidylcholine. Circulation. 2002; 106:31113119.

14. Kim MY, Liang GH, Kim JA, Choi SS, Choi S and Suh SH. Oxidized Low-density Lipoprotein- and Lysophosphatidylcholine-induced $\mathrm{Ca}$ Mobilization in Human Endothelial Cells. Korean J Physiol Pharmacol 2009; 13:27-32.

15. So I, Chae MR, Kim SJ and Lee SW. Lysophosphatidylcholine, a component of atherogenic lipoproteins, induces the change of calcium mobilization via TRPC ion channels in cultured human corporal smooth muscle cells. Int J Impot Res. 2005; 17:475-483.

16. Pedersen SF, Owsianik G and Nilius B. TRP channels: an overview. Cell Calcium. 2005; 38:233-252.

17. Hsieh CC, Yen MH, Liu HW and Lau YT. Lysophosphatidylcholine induces apoptotic and nonapoptotic death in vascular smooth muscle cells: in comparison with oxidized LDL. Atherosclerosis. 2000; 151:481-491.

18. Jackson WF. Ion channels and vascular tone. Hypertension. 2000; 35:173-178.

19. Parekh AB and Putney JW, Jr. Store-operated calcium channels. Physiol Rev. 2005; 85:757-810.

20. Yuan JP, Lee KP, Hong JH and Muallem S. The closing and opening of TRPC channels by Homer1 and STIM1. Acta Physiol (Oxf). 2012; 204:238-247.

21. Satoh H, Ginsburg KS, Qing K, Terada H, Hayashi H and Bers DM. KB-R7943 block of $\mathrm{Ca}(2+)$ influx via $\mathrm{Na}(+) /$ $\mathrm{Ca}(2+)$ exchange does not alter twitches or glycoside inotropy but prevents $\mathrm{Ca}(2+)$ overload in rat ventricular myocytes. Circulation. 2000; 101:1441-1446.

22. Schroder UH, Breder J, Sabelhaus CF and Reymann KG. The novel $\mathrm{Na}^{+} / \mathrm{Ca}^{2+}$ exchange inhibitor KB-R7943 protects CA1 neurons in rat hippocampal slices against hypoxic/ hypoglycemic injury. Neuropharmacology. 1999; 38:319321.

23. Merritt JE, Armstrong WP, Benham CD, Hallam TJ, Jacob R, Jaxa-Chamiec A, Leigh BK, McCarthy SA, Moores KE and Rink TJ. SK\&F 96365, a novel inhibitor of receptormediated calcium entry. Biochem J. 1990; 271:515-522.

24. Kiyonaka S, Kato K, Nishida M, Mio K, Numaga T, Sawaguchi Y, Yoshida T, Wakamori M, Mori E, Numata T, Ishii M, Takemoto H, Ojida A, Watanabe K, Uemura A, Kurose H, et al. Selective and direct inhibition of TRPC3 channels underlies biological activities of a pyrazole compound. Proc Natl Acad Sci U S A. 2009; 106:54005405.

25. Muraki K, Iwata $\mathrm{Y}$, Katanosaka $\mathrm{Y}$, Ito $\mathrm{T}$, Ohya $\mathrm{S}$, Shigekawa M and Imaizumi Y. TRPV2 is a component of osmotically sensitive cation channels in murine aortic myocytes. Circ Res. 2003; 93:829-838.

26. Vriens J, Appendino G and Nilius B. Pharmacology of vanilloid transient receptor potential cation channels. Mol Pharmacol. 2009; 75:1262-1279.

27. Schmitz G and Ruebsaamen K. Metabolism and atherogenic disease association of lysophosphatidylcholine. Atherosclerosis. 2010; 208:10-18.

28. Rabini RA, Galassi R, Fumelli P, Dousset N, Solera ML, Valdiguie P, Curatola G, Ferretti G, Taus M and Mazzanti L. Reduced $\mathrm{Na}^{+}-\mathrm{K}^{+}$-ATPase activity and plasma lysophosphatidylcholine concentrations in diabetic patients. Diabetes. 1994; 43:915-919.

29. Xu Y, Xiao YJ, Zhu K, Baudhuin LM, Lu J, Hong G, Kim KS, Cristina KL, Song L, F SW, Elson P, Markman M and Belinson J. Unfolding the pathophysiological role of bioactive lysophospholipids. Curr Drug Targets Immune Endocr Metabol Disord. 2003; 3:23-32.

30. Portman OW and Alexander M. Lysophosphatidylcholine concentrations and metabolism in aortic intima plus inner media: effect of nutritionally induced atherosclerosis. J Lipid Res. 1969; 10:158-165.

31. Ogita T, Tanaka Y, Nakaoka T, Matsuoka R, Kira Y, Nakamura M, Shimizu $\mathrm{T}$ and Fujita $\mathrm{T}$. Lysophosphatidylcholine transduces $\mathrm{Ca}^{2+}$ signaling via the platelet-activating factor receptor in macrophages. Am J Physiol. 1997; 272:H17-24.

32. Liu E, Goldhaber JI and Weiss JN. Effects of lysophosphatidylcholine on electrophysiological properties 
and excitation-contraction coupling in isolated guinea pig ventricular myocytes. J Clin Invest. 1991; 88:1819-1832.

33. Woodley SL, Ikenouchi $\mathrm{H}$ and Barry WH. Lysophosphatidylcholine increases cytosolic calcium in ventricular myocytes by direct action on the sarcolemma. J Mol Cell Cardiol. 1991; 23:671-680.

34. Li L, Matsuoka I, Sakamoto K and Kimura J. Differential effects of lysophosphatidylcholine and $\mathrm{ACh}$ on muscarinic $\mathrm{K}^{+}$, non-selective cation and $\mathrm{Ca}^{2+}$ currents in guinea-pig atrial cells. Fukushima J Med Sci. 2016; 62:27-35.

35. Fearon IM. OxLDL enhances L-type $\mathrm{Ca}^{2+}$ currents via lysophosphatidylcholine-induced mitochondrial reactive oxygen species (ROS) production. Cardiovasc Res. 2006; 69:855-864.

36. Jung $\mathrm{S}$, Lee $\mathrm{Y}$, Han $\mathrm{S}$, Kim $\mathrm{Y}$, Nam $\mathrm{T}$ and Ahn D. Lysophosphatidylcholine Increases $\mathrm{Ca}$ Current via Activation of Protein Kinase C in Rabbit Portal Vein Smooth Muscle Cells. The Korean journal of physiology \& pharmacology. 2008; 12:31-35.

37. Wang $\mathrm{P}$, Wang $\mathrm{Q}$, Yang $\mathrm{L}$, Qin QL and Wu YJ. Characterization of lysophosphatidylcholine-induced changes of intracellular calcium in Drosophila S2 cells. Life Sci. 2015; 131:57-62.

38. Tanaka T, Ikeda K, Yamamoto Y, Iida H, Kikuchi H, Morita T, Yamasoba T, Nagai R and Nakajima T. Effects of serum amyloid A and lysophosphatidylcholine on intracellular calcium concentration in human coronary artery smooth muscle cells. Int Heart J. 2011; 52:185-193.

39. Liang GH, Park S, Kim MY, Kim JA, Choi S and Suh SH. Modulation of nonselective cation current by oxidized LDL and lysophosphatidylcholine and its inhibitory contribution to endothelial damage. Life Sci. 2010; 86:733-739.

40. Pinton P, Giorgi C, Siviero R, Zecchini E and Rizzuto R. Calcium and apoptosis: ER-mitochondria $\mathrm{Ca} 2+$ transfer in the control of apoptosis. Oncogene. 2008; 27:6407-6418.

41. Bennett MR. Apoptosis of vascular smooth muscle cells in vascular remodelling and atherosclerotic plaque rupture. Cardiovasc Res. 1999; 41:361-368.

42. Clarke MC, Littlewood TD, Figg N, Maguire JJ, Davenport AP, Goddard M and Bennett MR. Chronic apoptosis of vascular smooth muscle cells accelerates atherosclerosis and promotes calcification and medial degeneration. Circ Res. 2008; 102:1529-1538.

43. Tucka J, Yu H, Gray K, Figg N, Maguire J, Lam B, Bennett $\mathrm{M}$ and Littlewood T. Akt1 regulates vascular smooth muscle cell apoptosis through FoxO3a and Apaf1 and protects against arterial remodeling and atherosclerosis. Arterioscler Thromb Vasc Biol. 2014; 34:2421-2428.

44. Sasaki H, Watanabe F, Murano T, Miyashita Y and Shirai $\mathrm{K}$. Vascular smooth muscle cell apoptosis induced by 7-ketocholesterol was mediated via $\mathrm{Ca}^{2+}$ and inhibited by the calcium channel blocker nifedipine. Metabolism. 2007; $56: 357-362$

45. Hsu JH, Wu JR, Liou SF, Chen HM, Dai ZK,
Chen IJ and Yeh JL. Labedipinedilol-A prevents lysophosphatidylcholine-induced vascular smooth muscle cell death through reducing reactive oxygen species production and anti-apoptosis. Atherosclerosis. 2011; 217:379-386.

46. Hajnoczky G, Davies E and Madesh M. Calcium signaling and apoptosis. Biochem Biophys Res Commun. 2003; 304:445-454.

47. Tombal B, Denmeade SR and Isaacs JT. Assessment and validation of a microinjection method for kinetic analysis of $[\mathrm{Ca} 2+] \mathrm{i}$ in individual cells undergoing apoptosis. Cell Calcium. 1999; 25:19-28.

48. Lynch K, Fernandez G, Pappalardo A and Peluso JJ. Basic fibroblast growth factor inhibits apoptosis of spontaneously immortalized granulosa cells by regulating intracellular free calcium levels through a protein kinase Cdelta-dependent pathway. Endocrinology. 2000; 141:4209-4217.

49. Wu X, Eder P, Chang B and Molkentin JD. TRPC channels are necessary mediators of pathologic cardiac hypertrophy. Proc Natl Acad Sci U S A. 2010; 107:7000-7005.

50. Camacho Londono JE, Tian Q, Hammer K, Schroder L, Camacho Londono J, Reil JC, He T, Oberhofer M, Mannebach S, Mathar I, Philipp SE, Tabellion W, Schweda F, Dietrich A, Kaestner L, Laufs U, et al. A background $\mathrm{Ca} 2+$ entry pathway mediated by TRPC1/TRPC4 is critical for development of pathological cardiac remodelling. Eur Heart J. 2015; 36:2257-2266.

51. Che H, Li G, Sun HY, Xiao GS, Wang Y and Li GR. Roles of store-operated $\mathrm{Ca}^{2+}$ channels in regulating cell cycling and migration of human cardiac c-kit ${ }^{+}$progenitor cells. Am J Physiol Heart Circ Physiol. 2015; 309:H1772-1781.

52. Zhang YH, Wu HJ, Che H, Sun HY, Cheng LC, Li X, $\mathrm{Au}$ WK, Tse HF and Li GR. Functional transient receptor potential canonical type 1 channels in human atrial myocytes. Pflugers Archiv. 2013; 465:1439-1449.

53. Chen JB, Tao R, Sun HY, Tse HF, Lau CP and Li GR. Multiple $\mathrm{Ca}^{2+}$ signaling pathways regulate intracellular $\mathrm{Ca}^{2+}$ activity in human cardiac fibroblasts. J Cell Physiol. 2010; 223:68-75.

54. Li GR, Sun H, Deng X and Lau CP. Characterization of ionic currents in human mesenchymal stem cells from bone marrow. Stem cells. 2005; 23:371-382.

55. Wang WJ, Wang Y, Chen HZ, Xing YZ, Li FW, Zhang Q, Zhou B, Zhang HK, Zhang J, Bian XL, Li L, Liu Y, Zhao BX, Chen Y, Wu R, Li AZ, et al. Orphan nuclear receptor TR3 acts in autophagic cell death via mitochondrial signaling pathway. Nat Chem Biol. 2014; 10:133-140.

56. Tao R, Lau CP, Tse HF and Li GR. Regulation of cell proliferation by intermediate-conductance $\mathrm{Ca} 2+$-activated potassium and volume-sensitive chloride channels in mouse mesenchymal stem cells. Am J Physiol Cell Physiol. 2008; 295:C1409-1416. 